\title{
Homoleptic tetraazaphenanthrene-based copper(I) complexes: Synthesis, spectroscopic characterization, crystal structures and computational studies
}

\author{
Reza Kia ${ }^{\mathrm{a}, \mathrm{b}, \mathrm{c}, *}$, Mirko Scholz ${ }^{\mathrm{b}}$, Paul R. Raithby ${ }^{\mathrm{d}}$, Simone Techert ${ }^{\mathrm{b}, \mathrm{c}}$ \\ ${ }^{a}$ Chemistry Department, Sharif University of Technology, P.O. Box 11155-3516, Tehran, Iran \\ ${ }^{\mathrm{b}}$ Max Planck Institute for Biophysical Chemistry, Structural Dynamics for (Bio)chemical Systems, Am Fassberg 11, 37077 Göttingen, Germany \\ ${ }^{\mathrm{c}}$ FS-SCS, Deutsches Elektronen-Synchrotron (DESY), Notkestr. 85, 22607 Hamburg, Germany \\ ${ }^{\mathrm{d}}$ Department of Chemistry, University of Bath, BA2 7AY Bath, UK
}

\section{A R T I C L E I N F O}

\section{Article history:}

Received 28 June 2014

Received in revised form 9 August 2014

Accepted 13 August 2014

Available online 4 September 2014

\section{Keywords:}

Tetraazaphenanthrene

$\mathrm{Cu}(\mathrm{I})$ complexes

Bis(imine) complexes

DFT/TD-DFT

\begin{abstract}
A B S T R A C T
Three new $\mathrm{Cu}(\mathrm{I})$ complexes containing bidentate $\mathrm{N}^{\wedge} \mathrm{N}$ donor ligands with the general formula $\left[\mathrm{Cu}\left(\mathrm{N}^{\wedge} \mathrm{N}\right)_{2}\right]\left[\mathrm{PF}_{6}\right] \quad\left(\mathrm{N}^{\wedge} \mathrm{N}=2,3\right.$-diphenyl-6,7-di-p-tolyl-1,4,5,8-tetraazaphenanthrene $\left(\mathbf{L}^{\mathbf{1}}\right), \quad$ 2,3-diphenyl6,7-di(2-thienyl)-1,4,5,8-tetraazaphenanthrene $\left(\mathbf{L}^{\mathbf{2}}\right)$, and 2,3-diphenyl-6,7-di-p-fluorophenyl-1,4,5,8-tetraazaphenanthrene $\left(\mathbf{L}^{3}\right)$, were prepared by the reaction of $\left[\mathrm{Cu}\left(\mathrm{CH}_{3} \mathrm{CN}\right)_{4}\right]\left[\mathrm{PF}_{6}\right]$ with two equivalents of the $\mathrm{N}^{\wedge} \mathrm{N}$ ligand. Single-crystal X-ray diffraction analysis confirmed that in each complex the metal displays a distorted tetrahedral geometry surrounded by the four $\mathrm{N}$ atoms of the two sterically hindered substituted tetraazaphenanthrene (TAP) ligands. Density functional theory (DFT) and time-dependent density functional theory (TD-DFT), calculations were used to study the ground state properties and interpret the absorption spectra for these $\mathrm{Cu}(\mathrm{I})$ complexes. The calculations show that the lowest-energy excitations of all complexes are dominated by $\mathrm{d} \pi(\mathbf{C u}) \rightarrow \pi^{*}(\mathbf{L})$, metal-to-ligand charge transfer, (MLCT) excitations. Electronic difference density maps (EDDMs) were calculated, indicating the change of electron density in the singlet excited states. The degree of filling of the coordination sphere (G parameter) by the ligands was calculated taking into account the ligand-ligand overlap, and compared to the related bis(2,9-disubstituted phenanthroline) $\mathrm{Cu}(\mathrm{I})$ complexes.
\end{abstract}

(C) 2014 Elsevier B.V. All rights reserved.

\section{Introduction}

There has been much interest over the past two decades in emissive coordination complexes of the transition metal elements with a focus on their applications as photosensitizers in solarenergy conversion [1,2], in display devices [3], in phototherapy [4], as photo-catalysts [5], and as dopants to increase the efficiency of organic light emitting diodes (OLED) [6-8]. In this regard, first row transition metal complexes are potentially useful, being considered inexpensive, being less toxic, displaying a greater ease of synthesis, and are more abundant when compared to the thirdrow noble metal complexes. In particular, copper(I) diimine complexes have been considered as potential substitutes for ruthenium(II) and osmium(II) systems. Pioneering work toward elucidation of the unique photophysical and photochemical

\footnotetext{
* Corresponding author at: Chemistry Department, Sharif University of Technology, P.O. Box 11155-3516, Tehran, Iran. Tel.: +98 21 66165332; fax: +98 21 66029165.

E-mail addresses: rkia@sharif.edu,zsrkk@yahoo.com (R. Kia).
}

properties of $\left[\mathrm{Cu}^{\mathrm{I}}\left(\mathrm{N}^{\wedge} \mathrm{N}\right)_{2}\right]^{+}$complexes has been reported by McMillin and co-workers over the last 35 years [9-15]. Owing to the significant similarities in absorption spectra and photophysical behavior there have been recent attempt to replace $\mathrm{Ru}(\mathrm{II})$ with $\mathrm{Cu}(\mathrm{I})$ diimine complexes in dye-sensitized solar cells (DSSCs) [16-20]. However, the efficiencies and stabilities of the devices based on $\left[\mathrm{Cu}^{\mathrm{I}}\left(\mathrm{N}^{\wedge} \mathrm{N}\right)_{2}\right]^{+}$dyes, to date, are still inferior when compared to those of the Ru(II) dye-based solar cells because the MLCT states of $\mathrm{Cu}(\mathrm{I})$ diimine complexes undergo pseudo Jahn-Teller distortions, with significant structural reorganization, that are solvent-dependent and so the ${ }^{1}$ MLCT state lifetime can be influenced by the coordination geometry around $\mathrm{Cu}(\mathrm{I})$ center [20]. It is well known that the coordination chemistry of $\mathrm{Cu}(\mathrm{I})$ complexes is largely dependent on the electronic and steric effects of the coordinated ligands. In this context, ligands that can impose a tetrahedral or a pseudo-tetrahedral geometry on $\mathrm{Cu}(\mathrm{I})$ ions are interesting for a variety of reasons. This includes complexes that act as models for mononuclear $\mathrm{Cu}$ proteins [21], and as labile complexes in the general study of the structure-property relationships 
of transition metal complexes [22]. Because of the different geometries adopted by $\mathrm{Cu}(\mathrm{I})$ and $\mathrm{Cu}(\mathrm{II})$ complexes, their inter-conversion is accompanied by a pronounced structural change [21]. Moreover, the coordination geometry of these $\mathrm{Cu}$ complexes depends on the oxidation state of the $\mathrm{Cu}$ center. The $\mathrm{Cu}(\mathrm{I})\left(3 \mathrm{~d}^{10}\right)$ complexes in the ground state have a tetrahedral (or near tetrahedral) coordination geometry, whereas the $\mathrm{Cu}(\mathrm{II})\left(3 \mathrm{~d}^{9}\right)$ complexes in the MLCT excited state created upon photo-excitation prefer a more flattened tetrahedral (toward square planar) geometry with increased affinity for solvent ligation [23-25]. In this respect, $\mathrm{Cu}(\mathrm{I})$ complexes that contain heterocyclic diimine ligands have received more attention than other nitrogen-donor systems during the past few decades. However, studies of $\mathrm{Cu}(\mathrm{I})$ complexes with substituted 1,4,5,8-tetraazaphenanthrene (TAP) ligands, which show enhanced oxidizing properties compared to their phenanthroline counterparts are rare [26]. To date, there are only a few reports about the synthesis, characterization and properties of $\mathrm{Cu}(\mathrm{I})$-tetraazaphenanthrene complexes [26-28]. In order to exploit the spectroscopic and structural properties of $\mathrm{Cu}(\mathrm{I})$ 1,4,5,8-tetraazaphenanthrene-based complexes, we report the synthesis and full characterization of three new $\mathrm{Cu}(\mathrm{I})$ complexes of the unsymmetrical 2,3,6,7-substituted-1,4,5,8-tetraazaphenanthrene ligands. To the best of our knowledge [29,30], this is the first report on synthesis, characterization, crystal structures, and computational studies of unsymmetrical tetraazaphenanthrene $\mathrm{Cu}(\mathrm{I})$ complexes.

\section{Experimental}

\subsection{Materials, methods and instrumentation}

All reagents were purchased from Aldrich and used as received. All solvents were reagent grade and purified by standard techniques where required. Commercially available $\left[\mathrm{Cu}\left(\mathrm{CH}_{3} \mathrm{CN}\right)_{4}\right]\left[\mathrm{PF}_{6}\right]$ was used as received. The 2,3,6,7-substituted-1,4,5,8-tetraazaphenanthrene ligands (Scheme 1) were synthesized based on the literature method [28]. Infrared spectra in the region of $4000-400 \mathrm{~cm}^{-1}$ were recorded in $\mathrm{KBr}$ discs with a Bruker IFD 25 FT-IR spectrophotometer. Mass spectra were recorded on a Varian MS-500, ElectroSpray Ionization Mass Spectrometry (ESI-MS). Electronic absorption spectra in dichloromethane solutions were measured with a

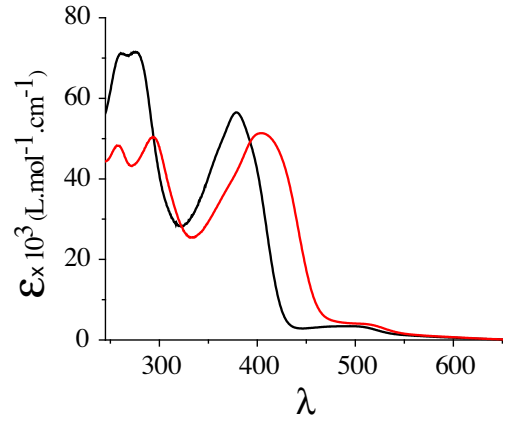

Fig. 1. Absorption spectrum of $\mathbf{1}\left(1.35 \times 10^{-5} \mathrm{M}\right.$, black $)$ and $\mathbf{2}\left(2.61 \times 10^{-5} \mathrm{M}\right.$, red $)$ in dichloromethane (the inset shows the low energy region). (For interpretation of the references to colour in this figure legend, the reader is referred to the web version of this article.)

CARY 5E spectrophotometer. The ${ }^{1} \mathrm{H}$ NMR spectra were recorded using Agilent Oxford $400 \mathrm{MHz}$ spectrometer in $\mathrm{CDCl}_{3}$ with tetramethylsilane (TMS) as an internal standard. The preparation of all the $\mathrm{Cu}(\mathrm{I})$ complexes (Scheme 1) has been achieved using literature methods [31]. Because of the insolubility of complex $\mathbf{3}$ in common organic solvents only CHN, IR, ESI-Mass and crystal structure data are reported in the experimental section.

\subsection{Synthesis of $\left[\mathrm{Cu}\left(L^{1}\right)_{2}\right] P F_{6}(\mathbf{1})$}

$\left[\mathrm{Cu}\left(\mathrm{CH}_{3} \mathrm{CN}\right)_{4}\right]\left[\mathrm{PF}_{6}\right](0.08 \mathrm{~g}, 0.25 \mathrm{mmol})$ was dissolved in $20 \mathrm{~mL}$ of dichloromethane in a $50 \mathrm{~mL}$ round bottom flask under an argon atmosphere. Then, $10 \mathrm{~mL}$ of a solution containing $0.26 \mathrm{~g}(0.5 \mathrm{mmol}$, 2 equiv.) of 2,3-diphenyl-6,7-di-p-tolyl-1,4,5,8-tetraazaphenanthrene $\left(\mathbf{L}^{\mathbf{1}}\right)$ was added. The mixture was left to stir at room temperature for $1 \mathrm{~h}$, after that time the total volume reduced to $c a .10 \mathrm{~mL}$ and $10 \mathrm{~mL}$ of methanol was added. By slow evaporation of the solution, suitable dark-red blocked shape single crystals for X-ray diffraction were obtained. Elemental analyses, Calc. : C, 69.87; H, 4.23; N, 9.05. Found: 69.80; $\mathrm{H}, 4.19 ; \mathrm{N}, 9.12 \%$. ESI-MS $(\mathrm{m} /$ $z)=1091\left[\mathrm{M}-\mathrm{PF}_{6}\right]^{+} . \mathrm{IR}\left(\mathrm{cm}^{-1}\right): 1608 \mathrm{w}, 1563 \mathrm{w}, 1527 \mathrm{w}, 1512 \mathrm{w}$, 1470w, 1442w, 1369vs, 1254s, 1227s, 1186s, 1108s, 836vs, 699s, 557s; ${ }^{1} \mathrm{H}$ NMR (400 MHz, $\mathrm{CDCl}_{3}$, r.t.) 8.49 (br. s, $\mathrm{H}_{9,10}$ ), 7.26-7.45<smiles></smiles>

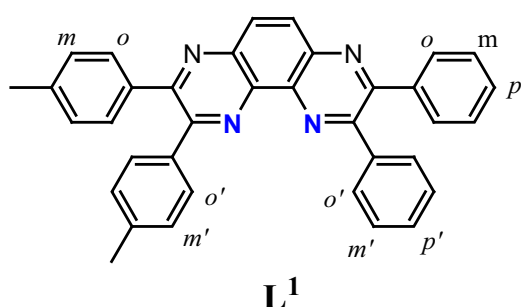

$\mathbf{L}^{1}$<smiles></smiles>

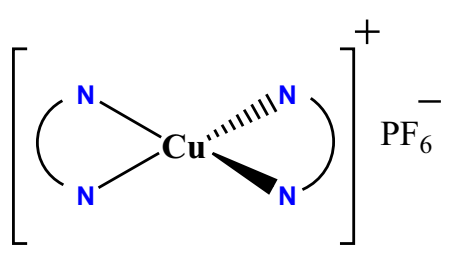<smiles>Fc1ccc(-c2nc3ccc4nc(-c5ccccc5)c(-c5ccccc5)nc4c3nc2-c2ccc(F)cc2)cc1</smiles>

$\mathbf{L}^{3}$

Scheme 1. The parent tetraazaphenanthrene core, 2,3,6,7-substituted tetraazaphenanthrene ligands and their related $\mathrm{Cu}(\mathrm{I})$ complex. 
Table 1

Crystal data and refinement parameters of complexes 1-3.

\begin{tabular}{|c|c|c|c|}
\hline Complex & 1 & 2 & 3 \\
\hline Empirical formula & $\mathrm{C}_{72} \mathrm{H}_{52} \mathrm{CuF}_{6} \mathrm{~N}_{8} \mathrm{P}$ & $\mathrm{C}_{60} \mathrm{H}_{36} \mathrm{CuF}_{6} \mathrm{~N}_{8} \mathrm{PS}_{4}$ & $\mathrm{C}_{68} \mathrm{H}_{40} \mathrm{CuF}_{10} \mathrm{~N}_{8} \mathrm{P}$ \\
\hline Formula mass & 1237.73 & 1205.72 & 1253.59 \\
\hline Crystal size (mm) & $0.10 \times 0.15 \times 0.25$ & $0.04 \times 0.08 \times 0.15$ & $0.10 \times 0.18 \times 0.35$ \\
\hline Colour & dark-red & dark-red & dark-red \\
\hline Crystal system & triclinic & triclinic & triclinic \\
\hline Space group & $P \overline{1}$ & $P \overline{1}$ & $P \overline{1}$ \\
\hline$\theta_{\max }\left({ }^{\circ}\right)$ & 26 & 72.50 & 72.50 \\
\hline$a(\AA)$ & $12.7941(4)$ & $12.4680(4)$ & $11.1088(4)$ \\
\hline$b(\AA)$ & $16.0106(5)$ & $13.3364(4)$ & $15.1156(5)$ \\
\hline$c(\AA)$ & $16.0151(5)$ & $17.4525(5)$ & $18.2193(6)$ \\
\hline$\alpha\left({ }^{\circ}\right)$ & $65.127(3)$ & $105.236(3)$ & $105.045(3)$ \\
\hline$\beta\left(^{\circ}\right)$ & $83.633(2)$ & $99.745(3)$ & $99.568(3)$ \\
\hline$\gamma\left({ }^{\circ}\right)$ & $85.192(3)$ & $106.481(3)$ & $104.833(3)$ \\
\hline$V\left(\AA^{3}\right)$ & $2955.38(5)$ & $2590.02(14)$ & $2765.87(16)$ \\
\hline$Z$ & 2 & 2 & 2 \\
\hline$D_{\text {calc }}\left(\mathrm{Mg} \mathrm{m}^{-3}\right)$ & 1.391 & 1.546 & 1.505 \\
\hline$\mu\left(\mathrm{mm}^{-1}\right)$ & 0.468 & 3.013 & 1.58 \\
\hline$F(000)$ & 1276 & 1228 & 1276 \\
\hline \multirow[t]{3}{*}{ Index ranges } & $-15 \leqslant h \leqslant 15$ & $-15 \leqslant h \leqslant 15$ & $-13 \leqslant h \leqslant 13$ \\
\hline & $-17 \leqslant k \leqslant 19$ & $-16 \leqslant k \leqslant 16$ & $-18 \leqslant k \leqslant 18$ \\
\hline & $-17 \leqslant l \leqslant 19$ & $-20 \leqslant l \leqslant 21$ & $-22 \leqslant l \leqslant 22$ \\
\hline No. of measured reflections & 22571 & 29380 & 17841 \\
\hline No. of independent reflections $/ R_{\text {int }}$ & $11535 / 0.0232$ & $10140 / 0.033$ & $17841 / 0.042$ \\
\hline No. of observed reflections $\mathrm{I}>2 \sigma(I)$ & 10040 & 10140 & 10140 \\
\hline No. of parameters & 795 & 724 & 794 \\
\hline Goodness-of-fit (GOF) & 1.029 & 1.035 & 1.035 \\
\hline$R_{1}$ (observed data) & 0.0536 & 0.0399 & 0.0673 \\
\hline$w R_{2}$ (all data) & 0.01381 & 0.109 & 0.1846 \\
\hline
\end{tabular}

( $\left.\mathrm{m}, \mathrm{H}_{o, o^{\prime}}\right), 6.88-7.11\left(\mathrm{~m}, \mathrm{H}_{p, p^{\prime}}\right), 6.31-6.73\left(\mathrm{~m}, \mathrm{H}_{m, m^{\prime}}\right), 2.34\left(\mathrm{~s},-\mathrm{CH}_{3}\right)$, 1.98 (s, $\left.-\mathrm{CH}_{3}\right)$; UV-Vis $\left(\lambda_{\max }, \mathrm{nm} ; \varepsilon\right): 275$ (71660), 387 (56600), 490 (3990), and 511 (shoulder).

\subsection{Synthesis of $\left[\mathrm{Cu}\left(L^{2}\right)_{2}\right] P F_{6}$ (2)}

Complex 2 was prepared with the same manner for 1 except that $0.25 \mathrm{~g}$ ( $0.5 \mathrm{mmol}, 2$ equiv.) of 2,3-diphenyl-6,7-di-(2-thienyl)-1,4,5,8-tetraazaphenanthrene ( $\left.\mathbf{L}^{2}\right)$ was used. Elemental analyses, Calc.: C, 59.77; H, 3.01; N, 9.29. Found: C, 59.68; H, 2.98; N, 9.18\%. ESI-MS $(\mathrm{m} / z)=1060\left[\mathrm{M}-\mathrm{PF}_{6}\right]^{+} . \mathrm{IR}\left(\mathrm{cm}^{-1}\right): 1564 \mathrm{w}, 1522 \mathrm{~m}$, $1442 \mathrm{w}, 1416 \mathrm{~m}, 1371 \mathrm{~s}, 1250 \mathrm{~m}, 1231 \mathrm{~m}, 1099 \mathrm{~s}, 836 \mathrm{vs}, 699 \mathrm{~s}$, 609m, 557s; ${ }^{1} \mathrm{H}$ NMR (400 MHz, $\mathrm{CDCl}_{3}$, r.t.) 8.43-8.52 (dd, $\mathrm{H}_{9,10}$ ), 7.26-7.56 ( $\left.\mathrm{m}, \mathrm{H}_{o, o^{\prime}} \& \mathrm{H}_{\mathrm{a}, \mathrm{a}^{\prime}}\right), 6.77-7.04\left(\mathrm{~m}, \mathrm{H}_{p, p^{\prime}} \& \mathrm{H}_{\mathrm{c}, \mathrm{c}^{\prime}}\right), 6.51-6.62$ $\left(\mathrm{m}, \mathrm{H}_{m, m^{\prime}} \& \mathrm{H}_{\mathrm{b}, \mathrm{b}^{\prime}}\right)$; UV-Vis $\left(\lambda_{\max }, \mathrm{nm} ; \varepsilon\right): 276$ (48275), 293 (50421), 405 (51340), and 511 (4904, shoulder).

Table 2

Selected bond lengths and angles.

\begin{tabular}{llll} 
Complex 1 & & & \\
$\mathrm{Cu}(1)-\mathrm{N}(1)$ & $2.027(2)$ & $\mathrm{N}(1)-\mathrm{Cu}(1)-\mathrm{N}(2)$ & $82.92(8)$ \\
$\mathrm{Cu}(1)-\mathrm{N}(2)$ & $2.111(2)$ & $\mathrm{N}(3)-\mathrm{Cu}(1)-\mathrm{N}(4)$ & $82.43(8)$ \\
$\mathrm{Cu}(1)-\mathrm{N}(3)$ & $2.002(2)$ & $\mathrm{N}(3)-\mathrm{Cu}(1)-\mathrm{N}(1)$ & $147.91(9)$ \\
$\mathrm{Cu}(1)-\mathrm{N}(4)$ & $2.165(2)$ & $\mathrm{N}(3)-\mathrm{Cu}(1)-\mathrm{N}(2)$ & $119.65(8)$ \\
& & $\mathrm{N}(1)-\mathrm{Cu}(1)-\mathrm{N}(4)$ & $120.40(8)$ \\
& & $\mathrm{N}(2)-\mathrm{Cu}(1)-\mathrm{N}(4)$ & $95.15(8)$ \\
Complex 2 & & & \\
$\mathrm{Cu}(1)-\mathrm{N}(1)$ & $2.0476(17)$ & $\mathrm{N}(1)-\mathrm{Cu}(1)-\mathrm{N}(2)$ & $82.51(7)$ \\
$\mathrm{Cu}(1)-\mathrm{N}(2)$ & $2.0510(17)$ & $\mathrm{N}(3)-\mathrm{Cu}(1)-\mathrm{N}(4)$ & $84.40(7)$ \\
$\mathrm{Cu}(1)-\mathrm{N}(3)$ & $2.0875(18)$ & $\mathrm{N}(3)-\mathrm{Cu}(1)-\mathrm{N}(1)$ & $122.16(7)$ \\
$\mathrm{Cu}(1)-\mathrm{N}(4)$ & $2.0149(17)$ & $\mathrm{N}(3)-\mathrm{Cu}(1)-\mathrm{N}(2)$ & $101.56(7)$ \\
& & $\mathrm{N}(1)-\mathrm{Cu}(1)-\mathrm{N}(4)$ & $135.62(7)$ \\
& & $\mathrm{N}(2)-\mathrm{Cu}(1)-\mathrm{N}(4)$ & $130.03(7)$ \\
$\mathrm{Complex} \mathrm{3}$ & & & \\
$\mathrm{Cu}(1)-\mathrm{N}(1)$ & $2.055(2)$ & $\mathrm{N}(1)-\mathrm{Cu}(1)-\mathrm{N}(2)$ & $82.98(9)$ \\
$\mathrm{Cu}(1)-\mathrm{N}(2)$ & $2.045(2)$ & $\mathrm{N}(3)-\mathrm{Cu}(1)-\mathrm{N}(4)$ & $83.77(9)$ \\
$\mathrm{Cu}(1)-\mathrm{N}(3)$ & $2.065(2)$ & $\mathrm{N}(3)-\mathrm{Cu}(1)-\mathrm{N}(1)$ & $107.71(9)$ \\
$\mathrm{Cu}(1)-\mathrm{N}(4)$ & $2.030(2)$ & $\mathrm{N}(3)-\mathrm{Cu}(1)-\mathrm{N}(2)$ & $131.67(9)$ \\
& & $\mathrm{N}(1)-\mathrm{Cu}(1)-\mathrm{N}(4)$ & $132.5(10)$ \\
& & $\mathrm{N}(2)-\mathrm{Cu}(1)-\mathrm{N}(4)$ & $123.85(9)$ \\
\hline
\end{tabular}

\subsection{Synthesis of $\left[\mathrm{Cu}\left(\mathrm{L}^{3}\right)_{2}\right] \mathrm{PF}_{6}(\mathbf{3})$}

Complex $\mathbf{3}$ was also prepared with the same procedure for $\mathbf{1}$ except that $0.26 \mathrm{~g}$ ( $0.5 \mathrm{mmol}, 2$ equiv.) of 2,3-diphenyl-6,7-di-pfluorophenyl-1,4,5,8-tetraazaphenanthrene $\left(\mathbf{L}_{\mathbf{3}}\right)$ was used. Elemental analyses, Calc.: C, 65.15; H, 3.22; N, 8.94. Found: C, 65.10; H, 3.15; N, 8.89\%. ESI-MS $(m / z)=1107\left[\mathrm{M}-\mathrm{PF}_{6}\right]^{+}$.

Table 3

Hydrogen bonding and $\mathrm{C}-\mathrm{H}^{\cdots} \pi$ interactions parameters in complexes 1-3.

\begin{tabular}{|c|c|c|c|c|}
\hline & $\mathrm{D}-\mathrm{H} \cdots \mathrm{A}$ & $\mathrm{H} \cdots \mathrm{A}(\AA)$ & $\mathrm{D} \cdots \mathrm{A}(\AA)$ & $\mathrm{D}-\mathrm{H} \cdots \mathrm{A}\left({ }^{\circ}\right)$ \\
\hline Complex 1 & $\begin{array}{l}\mathrm{C}(20)-\mathrm{H}(20 \mathrm{~A}) \cdots \mathrm{F}(2)^{\mathrm{i}} \\
\mathrm{C}(50)-\mathrm{H}(50 \mathrm{~A}) \cdots \mathrm{F}(3) \\
\mathrm{C}(21)-\mathrm{H}(21 \mathrm{~A}) \cdots \mathrm{Cg}(10)^{\mathrm{i}} \\
\mathrm{C}(21)-\mathrm{H}(48 \mathrm{~A}) \cdots \mathrm{Cg}(11)^{\mathrm{ii}} \\
\mathrm{C}(21)-\mathrm{H}(72 \mathrm{~B}) \cdots \mathrm{Cg}(12)^{\mathrm{iii}}\end{array}$ & $\begin{array}{l}2.54 \\
2.48 \\
2.60 \\
2.71 \\
2.57\end{array}$ & $\begin{array}{l}3.472(4) \\
3.387(5) \\
3.488(3) \\
3.450(3) \\
3.434(3)\end{array}$ & $\begin{array}{l}166 \\
159 \\
157 \\
136 \\
147\end{array}$ \\
\hline Complex $\mathbf{2}$ & $\begin{array}{l}\mathrm{C}(8)-\mathrm{H}(8 \mathrm{~A}) \cdots \mathrm{F}(4) \\
\mathrm{C}(26)-\mathrm{H}(26 \mathrm{~A}) \cdots \mathrm{N}(7)^{\mathrm{iv}} \\
\mathrm{C}(42)-\mathrm{H}(42 \mathrm{~A}) \cdots \mathrm{F}(1)^{\mathrm{v}} \\
\mathrm{C}(44)-\mathrm{H}(44 \mathrm{~A}) \cdots \mathrm{F}(5) \\
\mathrm{C}(55)-\mathrm{H}(55 \mathrm{~A}) \cdots \mathrm{F}(5)^{\mathrm{vi}} \\
\mathrm{C}(28)-\mathrm{H}(28 \mathrm{~A}) \cdots \mathrm{Cg}(\mathrm{IV})^{\mathrm{i}} \\
\mathrm{C}(30)-\mathrm{H}(30 \mathrm{~A}) \cdots \mathrm{Cg}(\mathrm{IX})^{\mathrm{vii}} \\
\mathrm{C}(50)-\mathrm{H}(50 \mathrm{~A}) \cdots \mathrm{Cg}(\mathrm{II})^{\mathrm{ii}}\end{array}$ & $\begin{array}{l}2.50 \\
2.52 \\
2.45 \\
2.45 \\
2.50 \\
2.79 \\
2.93 \\
2.74\end{array}$ & $\begin{array}{l}3.135(3) \\
3.396(3) \\
3.346(3) \\
3.360(3) \\
3.081(3) \\
3.560(3) \\
3.596(3) \\
3.647(3)\end{array}$ & $\begin{array}{l}157 \\
154 \\
157 \\
160 \\
119 \\
139 \\
129 \\
160\end{array}$ \\
\hline Complex 3 & $\begin{array}{l}\mathrm{C}(7)-\mathrm{H}(7 \mathrm{~A}) \cdots \mathrm{F}(5)^{\mathrm{viii}} \\
\mathrm{C}(8)-\mathrm{H}(8 \mathrm{~A}) \cdots \mathrm{F}(6)^{\mathrm{viii}} \\
\mathrm{C}(15)-\mathrm{H}(15 \mathrm{~A}) \cdots \mathrm{F}(2)^{\mathrm{ix}} \\
\mathrm{C}(34)-\mathrm{H}(34 \mathrm{~A}) \cdots \mathrm{F}(8)^{\mathrm{x}} \\
\mathrm{C}(41)-\mathrm{H}(41 \mathrm{~A}) \cdots \mathrm{F}(7)^{\mathrm{xi}} \\
\mathrm{C}(46)-\mathrm{H}(46 \mathrm{~A}) \cdots \mathrm{F}(9)^{\mathrm{x}} \\
\mathrm{C}(46)-\mathrm{H}(46 \mathrm{~A}) \cdots \mathrm{F}(10)^{\mathrm{x}} \\
\mathrm{C}(59)-\mathrm{H}(59 \mathrm{~A}) \cdots \mathrm{F}(1)^{\mathrm{xii}} \\
\mathrm{C}(68)-\mathrm{H}(68 \mathrm{~A}) \cdots \mathrm{F}(8) \\
\mathrm{C}(14)-\mathrm{H}(14 \mathrm{~A}) \cdots \mathrm{Cg}(\mathrm{G})^{\mathrm{xi}} \\
\mathrm{C}(48)-\mathrm{H}(48 \mathrm{~A}) \cdots \mathrm{Cg}(\mathrm{F})^{\mathrm{xii}} \\
\mathrm{C}(62)-\mathrm{H}(62 \mathrm{~A}) \cdots \mathrm{Cg}(\mathrm{A})^{\mathrm{ii}}\end{array}$ & $\begin{array}{l}2.50 \\
2.38 \\
2.53 \\
2.39 \\
2.50 \\
2.53 \\
2.36 \\
2.41 \\
2.38 \\
2.89 \\
2.81 \\
2.70\end{array}$ & $\begin{array}{l}3.352(3) \\
3.210(3) \\
3.293(4) \\
3.327(4) \\
3.219(4) \\
3.171(4) \\
3.137(4) \\
3.126(4) \\
3.145(4) \\
3.737(3) \\
3.690(4) \\
3.303(3)\end{array}$ & $\begin{array}{l}149 \\
146 \\
137 \\
169 \\
133 \\
125 \\
139 \\
132 \\
138 \\
150 \\
154 \\
122\end{array}$ \\
\hline
\end{tabular}

Symmetry codes: (i) $-1+x, y, z$; (ii) $x, y, z$; (iii) $1-x,-y,-z$; (iv) $1-x, 1-y,-z$; (v) $x,-1+y, z$; (vi) $1-x, 1-y, 1-z$; (vii) $1+x, y, z$; (viii) $2-x, 1-y, 1-z$; (ix) $-1+x$, $-1+y, z$; (x) $1+x, y, z$; (xi) $1-x,-y, 1-z$; (xii) $2-x, 1-y, 1-z$; (xiii) $2-x,-y$, $-z$. 
Table 4

The intra- and intermolecular $\pi \cdots \pi$ interactions in complexes 1-3.

\begin{tabular}{|c|c|c|}
\hline Complex & $\pi \cdots \pi$ & $\mathrm{d}\left(\pi^{\cdots} \pi\right)(\hat{\AA})$ \\
\hline \multirow[t]{9}{*}{1} & $\mathrm{Cg}^{1 \cdots} \mathrm{Cg}^{2 \mathrm{i}}$ & $3.5661(16)$ \\
\hline & $\mathrm{Cg}^{3 \cdots} \mathrm{Cg}^{4 \mathrm{ii}}$ & $3.6866(15)$ \\
\hline & $\mathrm{Cg}^{3 \cdots} \mathrm{Cg}^{2 \mathrm{i}}$ & $3.8641(18)$ \\
\hline & $\mathrm{Cg}^{5 \cdots} \mathrm{Cg}^{6 \mathrm{i}}$ & $3.6159(16)$ \\
\hline & $\mathrm{Cg}^{7 \cdots} \mathrm{Cg}^{8 \mathrm{iii}}$ & $3.8136(14)$ \\
\hline & $\mathrm{Cg}^{4 \cdots} \mathrm{Cg}^{3 \mathrm{ii}}$ & $3.6865(15)$ \\
\hline & $\mathrm{Cg}^{4 \cdots} \mathrm{Cg}^{4 \mathrm{ii}}$ & $3.6481(18)$ \\
\hline & $\mathrm{Cg}^{4 \cdots} \mathrm{Cg}^{2 \mathrm{i}}$ & $3.6453(17)$ \\
\hline & $\mathrm{Cg}^{6 \cdots} \mathrm{Cg}^{8 \mathrm{i}}$ & $3.6050(15)$ \\
\hline \multirow[t]{5}{*}{2} & $\mathrm{Cg}^{\mathrm{I} \cdots} \mathrm{Cg}^{\mathrm{IIii}}$ & $3.5533(13)$ \\
\hline & $\mathrm{Cg}^{\mathrm{III}} \ldots \mathrm{Cg}^{\mathrm{IVi}}$ & $3.5391(13)$ \\
\hline & $\mathrm{Cg}^{\mathrm{V} \cdots \mathrm{Cg}^{\mathrm{Vliv}}}$ & $3.7080(13)$ \\
\hline & $\mathrm{Cg}^{\mathrm{VIII}} \ldots \mathrm{Cg}^{\mathrm{III}}$ & $3.6766(13)$ \\
\hline & $\mathrm{Cg}^{\mathrm{VIIII}} \cdot \mathrm{Cg}^{\mathrm{III}}$ & $3.6138(13)$ \\
\hline \multirow[t]{4}{*}{3} & $\mathrm{Cg}^{\mathrm{A}} \ldots \mathrm{Cg}^{\mathrm{Bi}}$ & $3.822(2)$ \\
\hline & $\mathrm{Cg}^{\mathrm{C}} \ldots \mathrm{Cg}^{\mathrm{Bi}}$ & $3.5692(2)$ \\
\hline & $\mathrm{Cg}^{\mathrm{E}} \ldots \mathrm{Cg}^{\mathrm{Bi}}$ & $3.603(2)$ \\
\hline & $\mathrm{Cg}^{\mathrm{F}} \ldots \mathrm{Cg}^{\mathrm{Di}}$ & $3.796(2)$ \\
\hline
\end{tabular}

Symmetry codes: (i) $x, y, z$; (ii) $1-x, 1-y,-y$; (iii) $1-x,-y, 1-z$; (iv) $1-x, 1-y$, $1-z ; \quad$ For $1, \quad \mathrm{Cg} 1=\mathrm{Cu} 1 / \mathrm{N} 1 / \mathrm{C} 4 / \mathrm{C} 5 / \mathrm{N} 2 ; \quad \mathrm{Cg} 2=\mathrm{C} 59-\mathrm{C} 64 ; \quad \mathrm{Cg} 3=\mathrm{N} 1 / \mathrm{N} 5 / \mathrm{C} 1-\mathrm{C} 4$; $\mathrm{Cg} 4=\mathrm{C} 3-\mathrm{C} 8 ; \mathrm{Cg} 5=\mathrm{N} 3 / \mathrm{N} 7 / \mathrm{C} 37-\mathrm{C} 40 ; \mathrm{Cg} 6=\mathrm{C} 23-\mathrm{C} 28 ; \mathrm{Cg} 7=\mathrm{N} 4 / \mathrm{N} 8 / \mathrm{C} 41 / \mathrm{C} 42 / \mathrm{C} 45 /$ $\mathrm{C} 46 ; \mathrm{Cg}=\mathrm{C} 39-\mathrm{C} 44 ;$ For $2, \mathrm{CgI}=\mathrm{Cu} 1 / \mathrm{N} 1 / \mathrm{N} 2 / \mathrm{C} 4 / \mathrm{C} 5 ; \mathrm{CgII}=\mathrm{C} 41-\mathrm{C} 46 ; \mathrm{CgIII}=\mathrm{Cu} 1 / \mathrm{N} 3$ $\mathrm{N} 4 / \mathrm{C} 34 / \mathrm{C} 35 ; \quad \mathrm{CgIV}=\mathrm{S} 1 / \mathrm{C} 23-\mathrm{C} 26 ; \quad \mathrm{CgV}=\mathrm{S} 2 / \mathrm{C} 27-\mathrm{C} 30 ; \quad \mathrm{CgVI}=\mathrm{N} 1 / \mathrm{N} 5 / \mathrm{C} 1-\mathrm{C} 4$; $\mathrm{CgVII}=\mathrm{N} 2 / \mathrm{N} 6 / \mathrm{C} 5 / \mathrm{C} 6 / \mathrm{C9} / \mathrm{C} 10 ; \quad \mathrm{CgVIII}=\mathrm{C} 3-\mathrm{C} 8 ; \quad$ For $3, \quad \mathrm{CgA}=\mathrm{Cu} 1 / \mathrm{N} 1 / \mathrm{N} 2 / \mathrm{C} 4 / \mathrm{C} 5$ $\mathrm{CgB}=\mathrm{C} 45-\mathrm{C} 50 ; \mathrm{CgC}=\mathrm{Cu} 1 / \mathrm{N} 4 / \mathrm{N} 5 / \mathrm{C} 38 / \mathrm{C} 39 ; \mathrm{CgD}=\mathrm{C} 11-\mathrm{C} 16 ; \quad \mathrm{CgE}=\mathrm{N} 1 / \mathrm{N} 6 / \mathrm{C} 1-\mathrm{C} 4 ;$ $\mathrm{CgF}=\mathrm{N} 4 / \mathrm{C} 35-\mathrm{C} 38$

\subsection{Crystal structure analysis}

Single crystals of $\mathbf{1}$ and $\mathbf{2}$ suitable for X-ray diffraction analysis, were grown by slow evaporation of the solutions of the complexes dissolved in a mixture (1/1) of dichloromethane and ethanol. In case of complex 3, the suitable single crystals were obtained directly from the reaction mixture by addition of ethanol to the dichloromethane solution by slow evaporation. X-ray intensity data were collected using the full sphere routine by $\varphi$ and $\omega$ scans strategy on the Agilent SuperNova dual wavelength CCD diffractometer with graphite monochromated Mo $\mathrm{K} \alpha$ radiation $(\lambda=0.71073 \AA)$ for $\mathbf{1}$ and $\mathrm{Cu} \mathrm{K} \alpha$ radiation $(\lambda=1.54184 \AA)$ for 2 and 3. For all data collections the crystals were cooled to $100 \mathrm{~K}$ using an Oxford Diffraction Cryojet low-temperature attachment. The data reduction, including an empirical absorption correction using spherical harmonics, implemented in SCALE3 ABSPACK scaling algorithm [32], was performed using the CrysAlisPro software package [33]. The crystal structures were solved by direct methods using the online version of AuthoChem 2.0 in conjunction with OLEX2 [34] suite of programs implemented in the CrysAlis software, and refined by full-matrix least-squares (sHeLXL-97) [35] on $F^{2}$. The non-hydrogen atoms were refined anisotropically. All of the hydrogen atoms were positioned geometrically in idealized positions and refined with the riding model approximation, with $U_{\text {iso }}(-$ $\mathrm{H})=1.2$ or $1.5 U_{\mathrm{eq}}(\mathrm{C})$. For the molecular graphics the program sHeLXTL [35] was used. The crystal structure of $\mathbf{1}$ showed some solvent accessible voids $\left(100 \AA^{3}\right)$. The contribution to the diffraction pattern of solvent molecules of crystallization in 1 could not be rigorously included in the model, and these were consequently removed with the SQUEEZE routine of PLATON [36]. In complex 1, the largest peak $\left(2.27 \mathrm{e} \AA^{-3}\right)$ is located $0.87 \AA$ from atom P1. The crystal of $\mathbf{3}$ was a non-merohedral twin with a refined $B A S F$ ratio of $0.384(1) / 0.616(1)$. All geometric calculations were carried out using the PLATON software. The degree of filling of the coordination sphere ( $\mathbf{G}$ parameter) by the ligands in complexes 1-3 was calculated using the Solid-G program [37], in order to obtain more information about the steric hindrance around metal atom, and

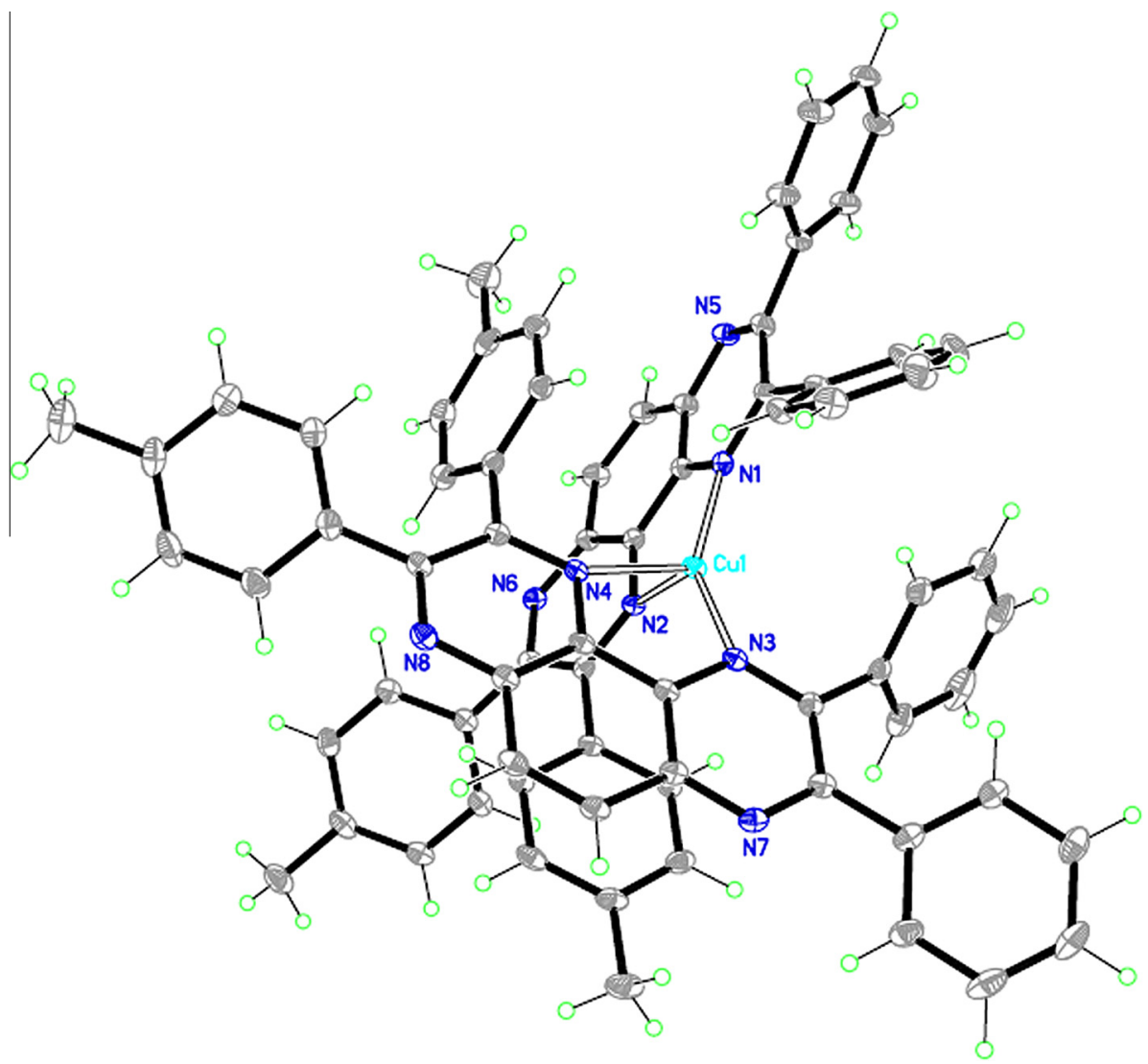

Fig. 2. The molecular structure of complex 1, with displacement ellipsoids at $50 \%$ probability and atom numbering scheme (the $\mathrm{PF}_{6}^{-}$anion was omitted for clarity). 


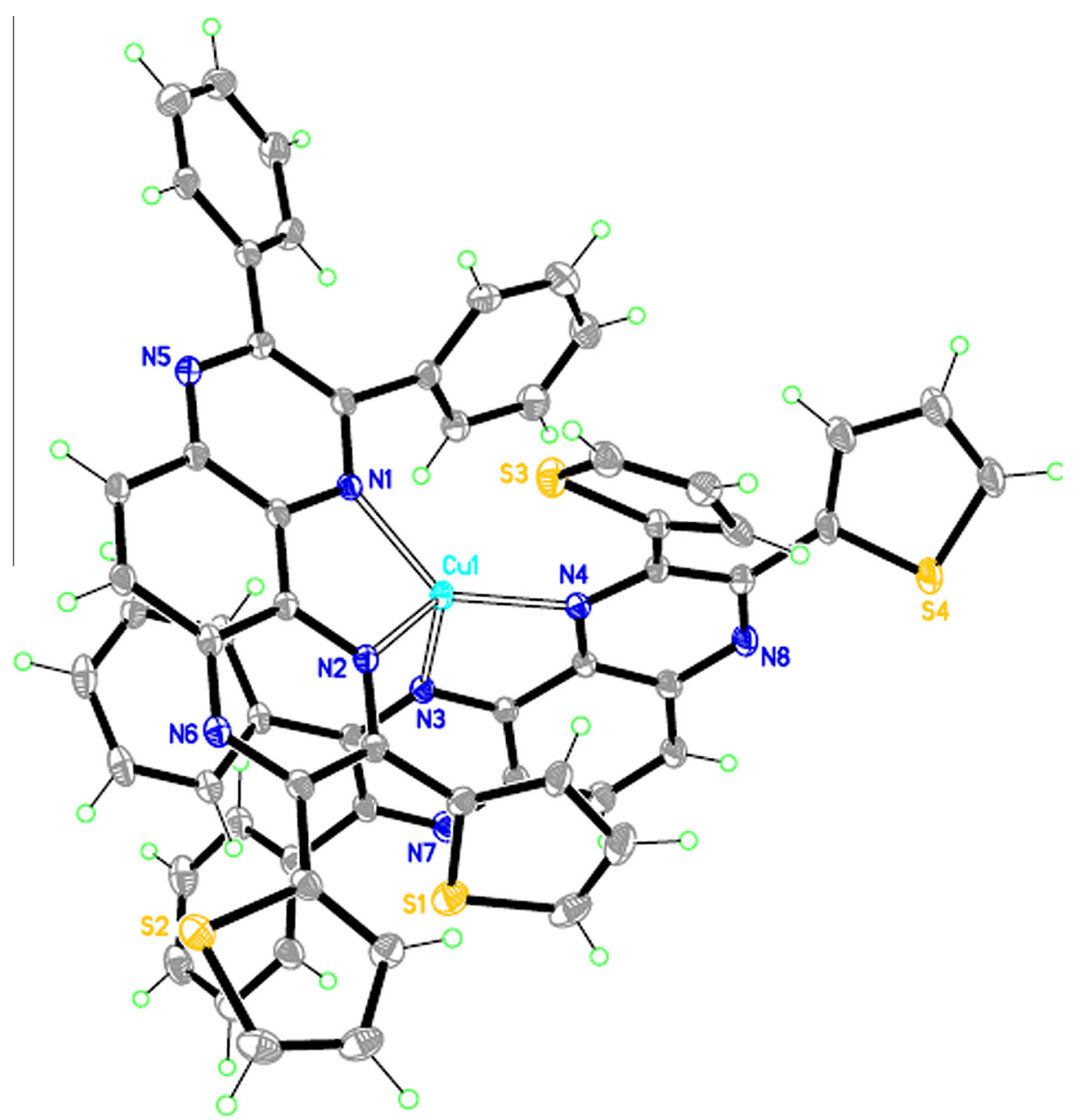

Fig. 3. The molecular structure of complex 2, with displacement ellipsoids at $50 \%$ probability and atom numbering scheme (the $\mathrm{PF}_{6}^{-}$anions were omitted for clarity).

compare to some 2,9-disubstituted phenanthroline-based $\mathrm{Cu}(\mathrm{I})$ complexes.

\section{Computational details}

For the ground state electronic structure calculations the DFT method with the Becke [38] three parameter hybrid functional and Lee-Yang-Parr's [39] gradient corrected correlation functional (B3LYP) was used. The calculations were performed with the GAussIAN03 (G03) [40] program. The Stuttgart-Dresden (SDD) [41,42] basis set and effective core potential (ECP) were used for the $\mathrm{Cu}$ atom and the $6-31 G^{*}$ (five pure $d$ functions) basis sets were used for all other atoms. Since solvent effects play an important role in the electronic structure of the $\mathrm{Cu}$ complexes, the conductor-like polarizable continuum model method (CPCM) [43-45] with dichloromethane as solvent was used to calculate the electronic structure and the excited states of the complex in solution. Timedependent density functional theory (TDDFT) $[42,46]$ calculations have provided excitation energies of the $\mathrm{Cu}$ complexes that agree with experiments. From the singlet ground state, optimized in the gas phase, 60 singlet excited states and the corresponding oscillator strengths have been determined with a TDDFT calculation using GAUSSIAN03. The TDDFT calculation does not provide the electronic structures of the excited states; however, the electronic distribution and the localization of the singlet excited states may be visualized using the electron density difference maps (EDDMs) [47]. GaussSum 2.2 [48] was used for EDDMs calculations and for the electronic spectrum simulation.

\section{Results and discussion}

\subsection{Characterization}

The homoleptic complexes 1-3 formed immediately after mixing the solution of $\left[\mathrm{Cu}\left(\mathrm{CH}_{3} \mathrm{CN}\right)_{4}\right] \mathrm{PF}_{6}$ and the corresponding ligands $\mathbf{L}^{\mathbf{1}}-\mathbf{L}^{\mathbf{3}}$, which is evidenced by the color change of the reaction mixture from colourless to dark-red. The complexes were found to be air-stable in solution and in the solid state. The complexes were characterized initially by Electro-Spray Ionization Mass Spectrometry (ESI-MS) in methanol. The experimental ESI-MS spectra of the complexes with their simulated patterns are shown in the supplementary material (Figs. S1-S3). In the case of complex 3, because of insolubility, a suspension of the complex in methanol was injected for ESI-MS. The observed molecular ion peaks were consistent with the expected cationic complexes in 1-3 as given in the experimental section. The ${ }^{1} \mathrm{H}$ NMR spectra of complexes $\mathbf{1}$ and $\mathbf{2}$ are shown in the supplementary material (Figs. S4 and S5). The chemical shifts $(\mathrm{ppm})$ of the protons in the complexes are in good agreement to the previously reported data for $\left[\mathrm{Cu}(\mathrm{tpTAP})_{2}\right]^{+}$and $\left[\mathrm{Cu}(\mathrm{dpp})_{2}\right]^{+}$in which tpTAP and dpp stand for 2,3,6,7-tetraphenyl-1,4,5,8-tetraazaphenanthrene and 2,9-diphenyl-1,10-phenanthroline, respectively $[27,49,50]$. The IR spectra of complexes 1-3 (Figs. S6-S8), recorded in the range $4000-400 \mathrm{~cm}^{-1}$, displayed two strong bands at 836 and $557 \mathrm{~cm}^{-1}$ for both 1 and 2 and at 840 and $556 \mathrm{~cm}^{-1}$ for 3 that can be attributed to the hexafluoridophosphate anion [51]. The electronic absorption spectra of complexes $\mathbf{1}$ and $\mathbf{2}$, recorded in $\mathrm{CH}_{2} \mathrm{Cl}_{2}$ solution in the range $250-600 \mathrm{~nm}$ (Fig. 1), have similar 


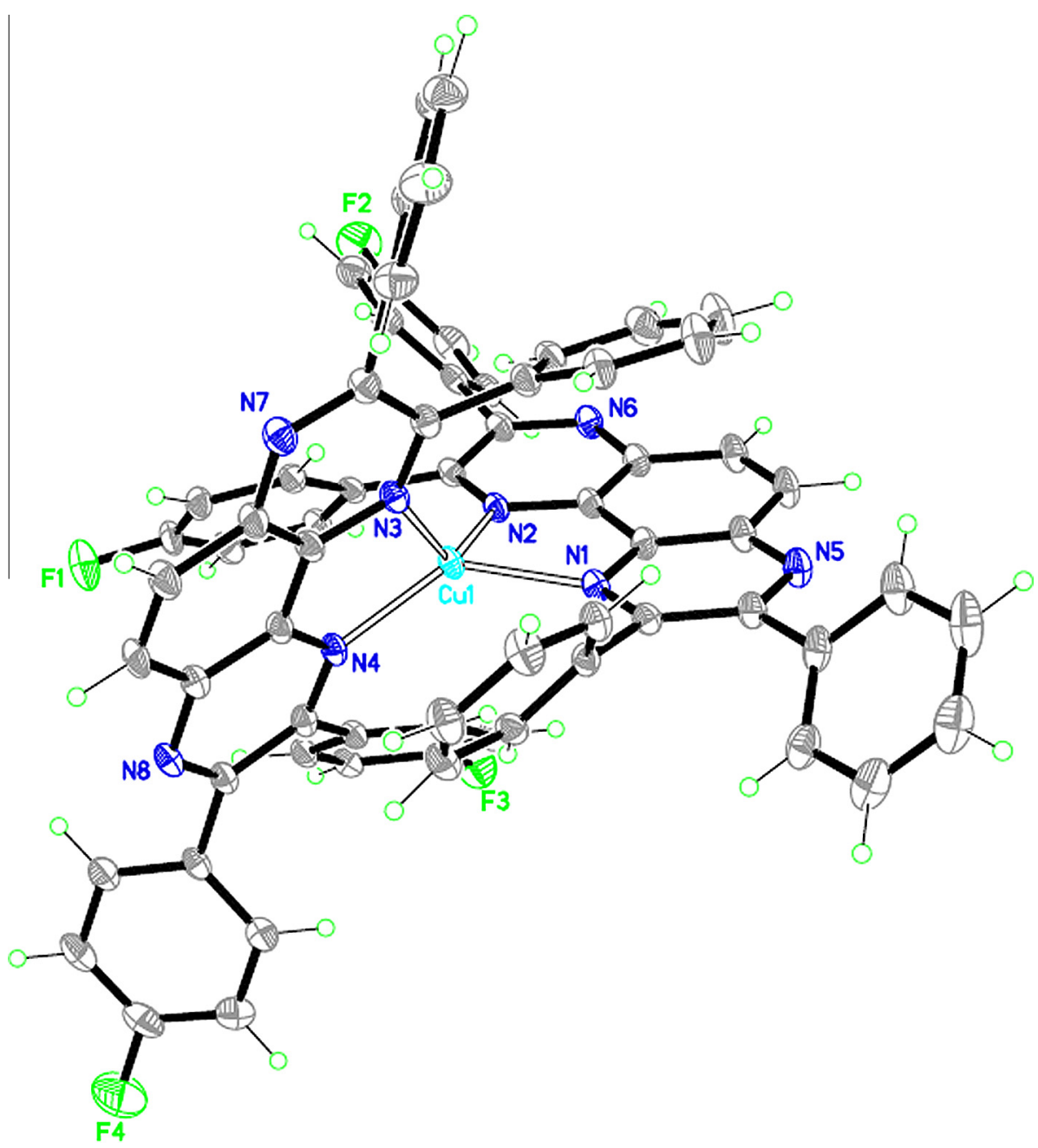

Fig. 4. The molecular structure of complex 3, with displacement ellipsoids at $50 \%$ probability and atom numbering scheme (the $\mathrm{PF}_{6}^{-}$anion was omitted for clarity).

Table 5

$\tau_{4}$ parameters and largest $\mathrm{N}-\mathrm{Cu}-\mathrm{N}$ bond angles for complexes 1-3.

\begin{tabular}{|c|c|c|c|}
\hline & {$\left[\mathrm{Cu}\left(\mathrm{L}^{1}\right)_{2}\right] \mathrm{PF}_{6}$} & {$\left[\mathrm{Cu}\left(\mathrm{L}^{2}\right)_{2}\right] \mathrm{PF}_{6}$} & {$\left[\mathrm{Cu}\left(\mathrm{L}^{3}\right)_{2}\right] \mathrm{PF}_{6}$} \\
\hline \multirow[t]{2}{*}{ Largest angles } & $\mathrm{N}(1)-\mathrm{Cu}(1)-\mathrm{N}(2)=147.91^{\circ}$ & $\mathrm{N}(1)-\mathrm{Cu}(1)-\mathrm{N}(2)=135.62^{\circ}$ & $\mathrm{N}(1)-\mathrm{Cu}(1)-\mathrm{N}(2)=132.5^{\circ}$ \\
\hline & $\mathrm{N}(3)-\mathrm{Cu}(1)-\mathrm{N}(4)=120.40^{\circ}$ & $\mathrm{N}(3)-\mathrm{Cu}(1)-\mathrm{N}(4)=122.16^{\circ}$ & $\mathrm{N}(3)-\mathrm{Cu}(1)-\mathrm{N}(4)=131.67^{\circ}$ \\
\hline$\tau_{4}$ & 0.65 & 0.72 & 0.68 \\
\hline
\end{tabular}

Table 6

Key geometric and steric parameters of complexes 1-3.

\begin{tabular}{|c|c|c|c|}
\hline Complex & $\mathbf{\Omega}(\mathrm{L})^{\mathrm{a}}$ & $\mathbf{G}(\text { Ligand })^{\mathrm{b}} \%$ & $(\text { Complex })^{\text {c\% }}$ \\
\hline \multirow[t]{2}{*}[\mathrm{Cu}(\mathrm{L}^{1})_{2}]{$\mathrm{PF}_{6}$} & 5.91 & 47.03 & 89.63 \\
\hline & 5.96 & 47.41 & \\
\hline \multirow[t]{2}{*}[\mathbf{Cu}(\mathbf{L}^{2})_{2}]{$\mathbf{P F}_{6}$} & 6.15 & 48.94 & 93.00 \\
\hline & 6.10 & 48.53 & \\
\hline \multirow{2}{*}[\mathbf{Cu}(\mathbf{L}^{3})_{2}]{$\mathbf{P F}_{6}$} & 6.20 & 49.37 & 92.68 \\
\hline & 6.03 & 47.96 & \\
\hline \multirow[t]{2}{*}{$\mathrm{Cu}\left(2,9 \mathrm{Me}_{2} \mathrm{Phen}_{2}\right] \mathrm{PF}_{6}$} & 6.16 & 49.05 & 78.22 \\
\hline & 5.92 & 47.12 & \\
\hline \multirow[t]{2}{*}{$\mathrm{Cu}\left(2,9 \mathrm{Phe}_{2} \mathrm{Phen}_{2}\right] \mathrm{PF}_{6}$} & 5.96 & 47.43 & 90.42 \\
\hline & 5.92 & 47.07 & \\
\hline \multirow[t]{2}{*}[\mathrm{Cu}(\mathrm{Me}_{4}\mathrm{Phe}_{2}\mathrm{Phen})_{2}]{$\mathrm{PF}_{6}$} & 6.16 & 49.05 & 92.39 \\
\hline & 5.92 & 47.12 & \\
\hline
\end{tabular}

a The solid angle of the ligand.

b The percentage of the sphere shielded by the ligand.

c The $G$ value for the complex, all ligands treated as one. features with a main absorption peak at 388 and $405 \mathrm{~nm}$, respectively, that can be attributed to mixed metal-to-ligand charge transfer (MLCT) and $\pi \rightarrow \pi^{*}$ transitions [52-54]. The higher energy region is dominated by an intense UV band at $275 \mathrm{~nm}$ for $\mathbf{1}$ and 2 which is assigned to $\pi \rightarrow \pi^{*}$ ligand-centered (LC) transitions. A shoulder on the red side of the absorption maximum has been assigned to low-lying MLCT transitions. The shoulder arises when either static or dynamic flattening distortion induces $D_{2 d}$ to $D_{2}$ symmetry transformation as reported previously [55-57]. According to the previous theoretical calculations (DFT) [56], the MLCT excited state flattening from the pseudo $D_{2 d}$ to $D_{2}$ symmetry effectively splits the nearly degenerate $\mathrm{Cu} 3 \mathrm{~d}_{x z}$ and $3 \mathrm{~d}_{y z}$ HOMO orbitals. These changes in 3d MO energy levels translate into an increased energy splitting between the two observed ${ }^{1}$ MLCT transitions that involve them, leading to a red-shift of the low-energy shoulder and a blue-shift of the main MLCT absorption peak. 

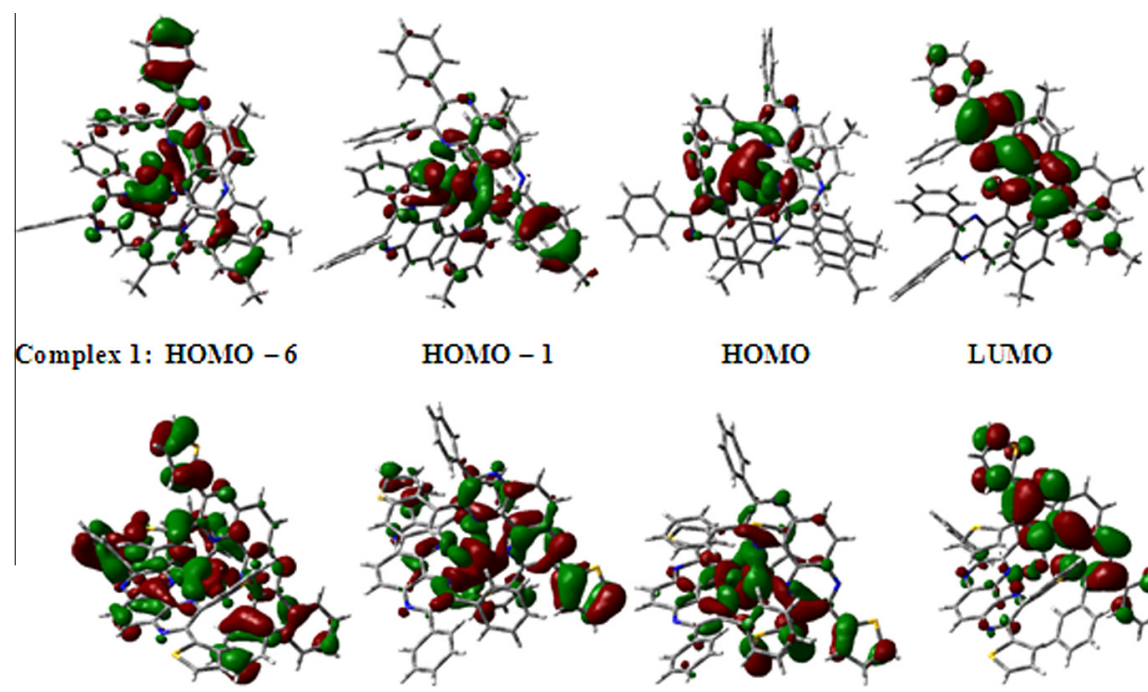

HOMO - 1

HOMO

LUMO

Complex 2: HOMO -6
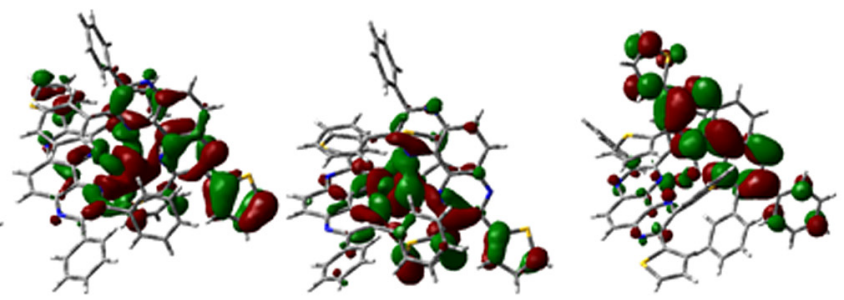

HOMO -3

HOMO

LUMO

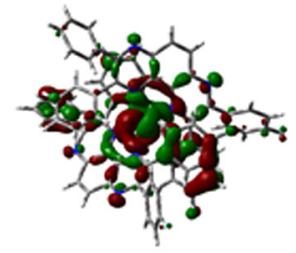

Complex 3: HOMO -6

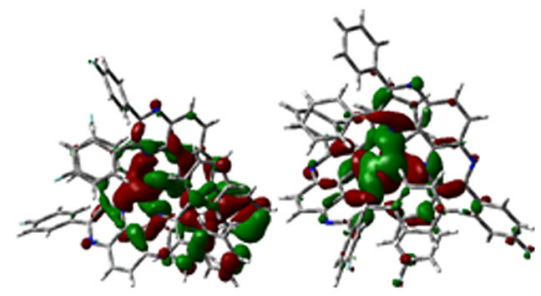

HOMO -3

HOMO

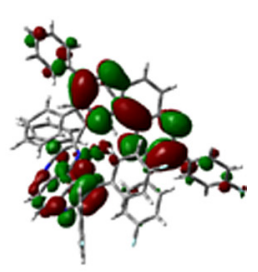

LUMO

Fig. 5. Selected frontier molecular orbitals of complexes 1-3.

\subsection{X-ray crystal structures}

Solid-state structural determination by single-crystal X-ray diffraction was performed on complexes 1-3. The crystallographic data and structural refinement parameters are summarized in Table 1. Selected bond lengths and angles are listed in Table 2. The details of intra- and intermolecular hydrogen bonding and $\mathrm{C}-\mathrm{H}^{\cdots} \pi$ interactions are listed in Table 3. Significant $\pi \cdots \pi$ interactions are present in complexes 1-3 which are summarized in Table 4. Block-shaped single crystals suitable for X-ray analysis were grown by slow evaporation of $\mathrm{CH}_{2} \mathrm{Cl}_{2} / \mathrm{CH}_{3} \mathrm{OH}(1 / 1)$ solution. In case of complex $\mathbf{3}$, the crystals were obtained directly by slow evaporation of the reaction mixture after addition of methanol. The crystal structures of complexes 1-3 are shown in Figs. 2-4. Complexes 1-3 crystallize in space group $P \overline{1}$ and display interesting intramolecular $\pi \cdots \pi$ and $\mathrm{C}-\mathrm{H}^{\cdots} \pi$ interactions between the peripheral aromatic rings and tetraazaphenanthrene core which affected the coordination geometry of the coordinated ligands around $\mathrm{Cu}(\mathrm{I})$ center. This type of intramolecular $\pi^{*} \pi$ stacking has also been observed in previously reported $\mathrm{Cu}(\mathrm{I})$ complexes incorporating dimesitylbipyridine and dipyridiophenazine ligands $[58,59]$. These interactions caused severe deviation from tetrahedral geometry in complexes 1-3 and of course each complex also has different intermolecular packing interactions as a result of the nature of the substituents. For confirming the effect of these intramolecular $\mathrm{C}-\mathrm{H}^{\cdots} \pi$ and $\pi \cdots \pi$ interactions on geometry around $\mathrm{Cu}(\mathrm{I})$ center, a quantitative approach to characterizing four-coordinate geometries based on the $\tau_{4}$ geometry index proposed by Houser [60] was performed for complexes 1-3. This method uses the equation $\tau_{4}=\left\{360^{\circ}-(\alpha+\beta)\right\} / 141^{\circ}$, where $\alpha$ and $\beta$ are the two largest angles in the four-coordinate geometry. The $\tau_{4}$ value of a perfect tetrahedron is 1.00 (largest angle of $109.5^{\circ}$ ), 0 for square planar (largest angle of $180^{\circ}$ ), and 0.85 for a perfect trigonal pyramidal (largest angle of $120^{\circ}$ ), and intermediate geometry fall within the range of $0-1.00$. The $\tau_{4}$ value for typical $\mathrm{Cu}(\mathrm{I})$ bis-diimine complexes such as $\left[\mathrm{Cu}(\mathrm{dmp})_{2}\right]^{+}$and $\left[\mathrm{Cu}\left(6,6^{\prime}\right.\right.$-dimethylbipyridine $\left.)_{2}\right]^{+}$are around 0.75 . $\mathrm{N}-\mathrm{Cu}-\mathrm{N}$ angles in these complexes range from $\approx 125^{\circ}$ to around $85^{\circ}$, the latter being found in the five-membered chelate rings. In complexes 1-3 all $\tau_{4}$ values are indicative of distorted trigonal-pyramidal geometry which is summarized in Table 5. The dihedral angle between the coordination planes $[\mathrm{N}(1)-\mathrm{Cu}(1)-\mathrm{N}(2)$ and $\mathrm{N}(3)-\mathrm{Cu}(1)-\mathrm{N}(2)]$ in complex $\mathbf{1 - 3}$ is $79.79(7)^{\circ}, 78.36(6)^{\circ}$, and $73.50(7)^{\circ}$, respectively. In supramolecular chemistry, weak interactions such as $\mathrm{C}-\mathrm{H}^{\cdots} \pi, \pi \cdots \pi$, and hydrogen bonding contribute significantly to the self-assembly and molecular recognition processes. For aromatic heterocycles, $\pi \cdots \pi$ interactions are commonly defined by the interplanar distances in the range of 3.3-3.8 $\AA$ [61]. Results of a search of the Cambridge Structural Database (CSD) [29] indicate that most $\pi \cdots \pi$ interactions of nitrogen-containing heterocyclic rings exist with a centroid-centroid distance of about $3.80 \AA$ and displacement angle up to $20^{\circ}$. Complex 1 shows some interesting intermolecular $\pi \cdots \pi$ interactions with centroid to centroid distances in the range of 3.6453(17) to $3.8136(14)$ Á with aliphatic and aromatic C-H groups involved in the intermolecular $\mathrm{C}-\mathrm{H}^{\cdots} \pi$ interactions. Another weaker interaction in complex $\mathbf{1}$ is the intermolecular hydrogen bonding involving the aromatic $\mathrm{C}-\mathrm{H}$ groups and the neighboring $\mathrm{PF}_{6}^{-}$anions. Complex 2 also shows the intermolecular $\pi \cdots \pi$ interaction with centroid to centroid distance of 3.7080(13) Á, intermolecular $\mathrm{C}-\mathrm{H}^{\cdots} \pi$ interactions and intramolecular and intermolecular $\mathrm{C}-\mathrm{H}^{\cdots} \mathrm{N}$ and $\mathrm{C}-\mathrm{H}^{\cdots} \mathrm{F}$ hydrogen bonds. Pair of centrosymmetric intermolecular $\mathrm{C}-\mathrm{H}^{\cdots} \mathrm{N}$ hydrogen bonds form individual dimers in the crystal packing of complex $\mathbf{2}$ (Fig. S9). Complex $\mathbf{3}$ shows an intermolecular $\pi^{\cdots} \pi$ stacking interaction with centroid 
Table 7

G03/B3LYP calculated one-electron energy and percentage composition of selected frontier MOs of $\mathbf{1}, \mathbf{2}$, and $\mathbf{3}$ expressed in terms of component fragments.

\begin{tabular}{|c|c|c|c|c|c|}
\hline MO & Energy (eV) & Character & $\mathrm{L}_{1}$ & $\mathrm{Cu}$ & $\mathrm{L}_{1}$ \\
\hline \multicolumn{6}{|c|}{ Complex 1} \\
\hline $285(\mathrm{~V})$ & -3.31 & Ligand & 95 & 2 & 3 \\
\hline 284(V) & -3.43 & Ligand & 1 & 2 & 97 \\
\hline $283(\mathrm{~V})$ & -4.42 & Ligand & 91 & 1 & 8 \\
\hline $282(\mathrm{~V})$ & -4.49 & Ligand & 7 & 1 & 92 \\
\hline $281(\mathrm{~V})$ & -4.59 & Ligand & 7 & 3 & 90 \\
\hline $280(\mathrm{~V})$ & -4.66 & Ligand & 92 & 3 & 5 \\
\hline $279(0)$ & -7.83 & $\mathrm{Cu}$ & 13 & 69 & 18 \\
\hline $278(0)$ & -7.92 & $\mathrm{Cu}+$ Ligand & 30 & 54 & 17 \\
\hline $277(0)$ & -8.13 & Ligand & 82 & 12 & 6 \\
\hline $276(0)$ & -8.16 & Ligand & 7 & 1 & 92 \\
\hline $275(0)$ & -8.45 & Ligand & 5 & 7 & 88 \\
\hline $274(0)$ & -8.47 & Ligand & 93 & 3 & 4 \\
\hline $273(0)$ & -8.61 & $\mathrm{Cu}+$ Ligand & 26 & 55 & 19 \\
\hline MO & Energy $(\mathrm{eV})$ & Character & $\mathrm{L}_{2}$ & $\mathrm{Cu}$ & $\mathrm{L}_{2}$ \\
\hline \multicolumn{6}{|c|}{ Complex 2} \\
\hline $273(V)$ & -3.65 & Ligand & 4 & 2 & 94 \\
\hline $272(V)$ & -3.85 & Ligand & 95 & 2 & 3 \\
\hline 271(V) & -4.66 & Ligand & 49 & 1 & 50 \\
\hline $270(V)$ & -4.68 & Ligand & 58 & 1 & 41 \\
\hline $269(\mathrm{~V})$ & -4.76 & Ligand & 82 & 3 & 15 \\
\hline $268(V)$ & -4.83 & Ligand & 7 & 2 & 91 \\
\hline $267(0)$ & -7.91 & $\mathrm{Cu}$ & 27 & 53 & 19 \\
\hline $266(0)$ & -7.98 & $\mathrm{Cu}+$ Ligand & 66 & 29 & 5 \\
\hline $265(0)$ & -8.08 & Ligand & 8 & 1 & 91 \\
\hline $264(0)$ & -8.19 & $\mathrm{Cu}+$ Ligand & 37 & 46 & 17 \\
\hline $263(0)$ & -8.48 & Ligand & 68 & 1 & 31 \\
\hline $262(0)$ & -8.56 & Ligand & 31 & 6 & 62 \\
\hline $261(0)$ & -8.67 & $\mathrm{Cu}+$ Ligand & 18 & 53 & 29 \\
\hline MO & Energy $(\mathrm{eV})$ & Character & $\mathrm{L}_{3}$ & $\mathrm{Cu}$ & $\mathrm{L}_{3}$ \\
\hline \multicolumn{6}{|c|}{ Complex 3} \\
\hline $285(\mathrm{~V})$ & -3.66 & Ligand & 52 & 1 & 47 \\
\hline $284(\mathrm{~V})$ & -3.81 & Ligand & 47 & 3 & 50 \\
\hline $283(V)$ & -4.80 & Ligand & 90 & 1 & 9 \\
\hline $282(\mathrm{~V})$ & -4.81 & Ligand & 7 & 1 & 92 \\
\hline $281(\mathrm{~V})$ & -4.87 & Ligand & 79 & 3 & 18 \\
\hline $280(\mathrm{~V})$ & -4.93 & Ligand & 19 & 3 & 78 \\
\hline $279(0)$ & -7.92 & $\mathrm{Cu}$ & 20 & 60 & 20 \\
\hline $278(0)$ & -8.38 & Ligand & 96 & 2 & 1 \\
\hline $277(0)$ & -8.42 & Ligand & 1 & 3 & 96 \\
\hline $276(0)$ & -8.57 & $\mathrm{Cu}+$ Ligand & 30 & 48 & 22 \\
\hline $275(0)$ & -8.62 & Ligand & 54 & 21 & 26 \\
\hline $274(0)$ & -8.75 & Ligand & 30 & 5 & 65 \\
\hline $273(0)$ & -8.85 & $\mathrm{Cu}+$ Ligand & 20 & 59 & 21 \\
\hline
\end{tabular}

Energy gap $(\Delta \mathrm{E})=3.17,2.91$, and $2.99 \mathrm{eV}$ (HOMO-LUMO), for 1, 2 and 3, respectively. The bold numbers are the values for the HOMO and LUMO of complexes 1-3. respectively.

to centroid distance of 3.9633(18) Á and also some intermolecular $\mathrm{C}-\mathrm{H}^{\cdots} \pi$ interactions. There are also a series of intermolecular $\mathrm{C}-$
$\mathrm{H} \cdots \mathrm{F}$ hydrogen bonds involving the aromatic $\mathrm{C}-\mathrm{H}$ groups and the neighboring $\mathrm{PF}_{6}^{-}$anions. These interactions make an aggregation of cations and anions into a one-dimensional chain along the $a$-axis (Fig. S10). Obviously, the geometric and steric characteristics of the complexes would be determined by the whole set of ligands incorporated in the coordination sphere. The degree of shielding of the central metal ion can serve as a measure of ligand-ligand noncovalent interactions. Therefore, in order to obtain a better understanding of the steric hindrance exerted by the coordinated ligands around the metal ion, the degree of filling of the coordination sphere by the tetraazaphenanthrene ligands in complexes 1-3 was calculated using the solid-G program considering the ligandligand overlap. The key geometric and steric parameters related to solid-G angle are summarized in Table 6 and are compared to some bis(2,9-disubstitutedphenanthroline) $\mathrm{Cu}(\mathrm{I})$ complexes.

\section{Computational studies}

\subsection{Electronic structure}

Since the observed differences in the chemical and physical properties of the complexes rely firstly on the changes in the ground-state electronic structure, we will discuss these features in detail with an emphasis on the frontier orbital components and HOMO-LUMO energy gaps. Selected important frontiers molecular orbitals for complexes 1-3 are depicted in Fig. 5. The data for the composition of the most important occupied and virtual orbitals and the atomic orbital contributions for each complex (\%) are listed in Table 7 . In the frontier region, neighboring orbitals are often closely spaced. In such cases, consideration of only the HOMO and LUMO may not yield a realistic description. For this reason, density of states (DOS) diagrams, which incorporate a degree of overlap between the curves convoluted from neighboring energy levels, can give a more representative picture. The density of states of 1-3 plotted as a function of orbital energy (eV) (Figs. S11-S13). Each complex is divided to three parts: the metal atom $(\mathrm{Cu})$ and the two coordinated tetraazaphenanthrene ligands. Each part of the percentage contributions are the sum of the atomic orbital coefficient squares. As shown in Fig. 5, the highest occupied orbitals in all complexes have predominant metal $\mathrm{Cu} \mathrm{d}$ character i.e., $69 \%, 53 \%$, and $60 \%$ in HOMO for $1-3$, respectively. The LUMO orbitals are primarily localized on the ligands, but not symmetrically as found previously in other complexes [61-64]. For complexes 1-3, the contribution for one ligand is $\sim 92 \%, 91 \%$, and $78 \%$ and for the other one is $5 \%, 7 \%$, and $19 \%$, respectively, and the remaining small contribution is distributed on the metal. Some lower-energy occupied MOs (HOMO-1 for 1, HOMO-1 and HOMO-3 for 2, and HOMO-3 for 3) still have significant metal character, but the contributions from the ligands increases. In contrast, the five lowest

Table 8

Selected TD-DFT calculated excitation energies and compositions of the lowest-lying singlet excited states for complexes 1-3.

\begin{tabular}{|c|c|c|c|c|c|}
\hline States & $\mathrm{E}(\mathrm{eV}) / \lambda(\mathrm{nm})$ & $f$ & $\lambda_{\text {exp. }}$ & Transition & Assignment \\
\hline \multicolumn{6}{|c|}{ Complex 1} \\
\hline 3 & $2.41 / 514$ & 0.051 & 496 & $\mathrm{H}-1 \rightarrow \mathrm{L}(54 \%) ; \mathrm{H}-1 \rightarrow \mathrm{L}+1(11 \%) ; \mathrm{H} \rightarrow \mathrm{L}(22 \%)$ & MLCT \\
\hline 11 & $3.044 / 407$ & 0.435 & 388 & $\mathrm{H}-6 \rightarrow \mathrm{L}+1(18 \%), \mathrm{H}-3 \rightarrow \mathrm{L}(12 \%), \mathrm{H}-2 \rightarrow \mathrm{L}(27 \%)$ & MLCT, $\pi \rightarrow \pi^{*}$ \\
\hline 58 & $3.86 / 321$ & 0.030 & 275 & $\mathrm{H}-10 \rightarrow \mathrm{L}+3(10 \%), \mathrm{H}-8 \rightarrow \mathrm{L}+2(18 \%)$ & $\pi \rightarrow \pi^{*}$ \\
\hline \multicolumn{6}{|c|}{ Complex 2} \\
\hline 3 & $2.38 / 521$ & 0.056 & 511 & $\mathrm{H}-1 \rightarrow \mathrm{L}(26 \%), \mathrm{H}-1 \rightarrow \mathrm{L}+1$ (27\%), H $\rightarrow \mathrm{L}+1$ (13\%) & MLCT \\
\hline 17 & $3.04 / 407$ & 0.028 & 405 & $\mathrm{H}-3 \rightarrow \mathrm{L}+1(12 \%), \mathrm{H}-3 \rightarrow \mathrm{L}+3(31 \%), \mathrm{H}-2 \rightarrow \mathrm{L}+3(27 \%)$ & MLCT, $\pi \rightarrow \pi^{*}$ \\
\hline 56 & $3.78 / 276$ & 0.10 & 327 & $\mathrm{H}-17 \rightarrow \mathrm{L}(33 \%), \mathrm{H}-9 \rightarrow \mathrm{L}+3(12 \%)$ & $\pi \rightarrow \pi^{*}$ \\
\hline \multicolumn{6}{|c|}{ Complex 3} \\
\hline 4 & $2.38 / 521$ & 0.014 & - & $\mathrm{H} \rightarrow \mathrm{L}+2$ (53\%), H $\rightarrow \mathrm{L}+3$ (41\%) & MLCT \\
\hline 12 & $3.05 / 406$ & 0.158 & - & $\mathrm{H}-3 \rightarrow \mathrm{L}(11 \%), \mathrm{H}-3 \rightarrow \mathrm{L}+2(21 \%), \mathrm{H}-2 \rightarrow \mathrm{L}(24 \%)$ & MLCT, $\pi \rightarrow \pi^{*}$ \\
\hline 59 & $3.86 / 321$ & 0.068 & - & $\mathrm{H}-10 \rightarrow \mathrm{L}+2(28 \%), \mathrm{H}-23 \rightarrow \mathrm{L}(3 \%)$ & $\pi \rightarrow \pi^{*}$ \\
\hline
\end{tabular}

$\mathrm{H}$ and $\mathrm{L}$ refer to the highest-occupied and lowest-unoccupied molecular orbitals, respectively. 

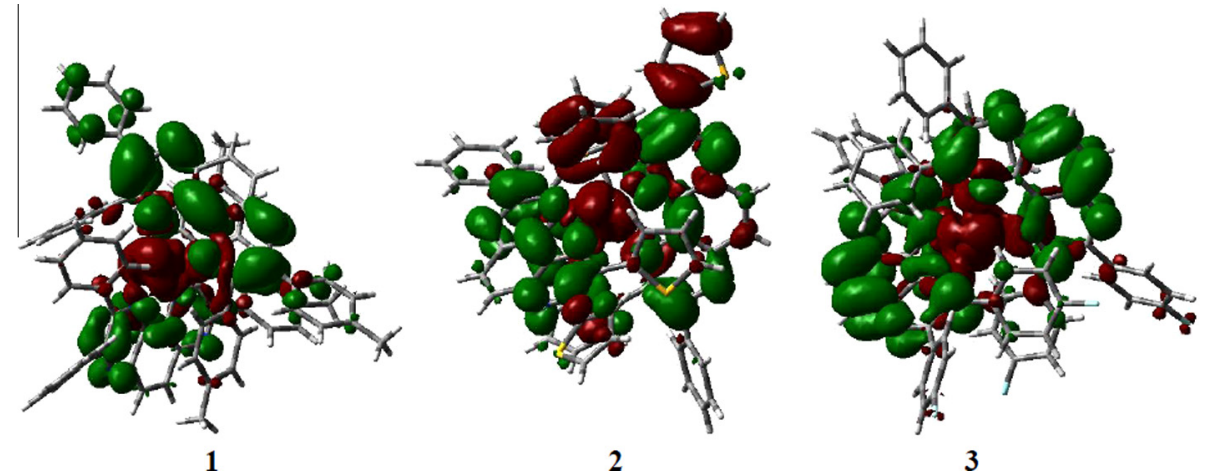

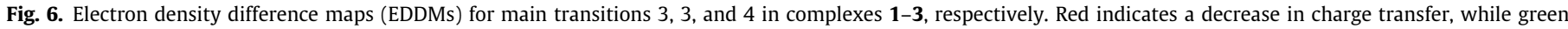
indicates an increase. (For interpretation of the references to colour in this figure legend, the reader is referred to the web version of this article.)

unoccupied orbitals above LUMO in each complex are essentially $\pi^{*}$-orbitals localized on the ligands. The energies of the orbitals for complexes 1-3 are similar since the ligands have similar $\pi$ structures. The HOMO-LUMO band gaps obtained from GAUSSIAN $03 \mathrm{MO}$ calculations for 1-3 were 3.17, 3.10, and $2.99 \mathrm{eV}$, respectively.

\subsection{Calculated electronic absorption spectra}

TD-DFT computations were performed to predict the electronic transition energies and intensities of the 60 lowest energy singlet transitions of the complexes. Selected low lying singlet excited states together with their vertical excitation energies, oscillator strengths and assignment for the complexes are displayed in Table 8. An experimental model for an excited state corresponds to the excitation of an electron from an occupied to a virtual molecular orbital (i.e., a one-electron picture). However, the excited states calculated herein demonstrate that excited-state electronic structures are best described in terms of multi-configurations, wherein a linear combination of several occupied-to-virtual MO excitations comprises a given optical transition. Assignment of the character of each excited state was based on the compositions of the occupied and virtual MOs of the dominant configuration(s) for that excited state. In principle, excited states that arise from transitions between orbitals that are located on different moieties are classified as charge transfer (CT) excited states. Those from $\pi$-occupied to $\pi$-unoccupied orbitals located on the same ligand are described as intra-ligand $\pi-\pi^{*}$ states (IL), but those from orbitals on different ligands are described as ligand-to-ligand charge transfer (LLCT) states. Metal-to-ligand charge transfer (MLCT) states involve transitions from the metal atom to ligandcentered orbitals which is very well-known in case of $\mathrm{Cu}(\mathrm{I}) \mathrm{com}-$ plexes with ligands having extended $\pi$ systems. The results from the TDDFT calculations agree with the experimental data for complexes $\mathbf{1}$ and $\mathbf{2}$ which are shown in supplementary materials (Fig. S14). Because of the insolubility of complex $\mathbf{3}$ in common organic solvents we were not able to record UV-Vis spectrum to compare with the theoretical calculations, therefore, only the calculated spectrum was reported and assigned. Electron density difference maps (EDDMs) derived from the TD-DFT calculations were used to show the electron density changes between the ground and excited states upon different electronic excitations. It represents a way for visualizing the electronic distribution, for which one can subtract the ground-state electron density $\left(\mathrm{S}_{0}\right)$ from the Franck-Condon electron density of the excited state, thereby providing a picture of the redistribution of the electron density after the vertical transition from the ground-state to any of the Franck-Condon excited states. Visualization of these difference density plots can provide an insight into the subsequent geometric changes occurring on the excited-state potential energy surface $[65,66]$, and to determine what type of excitation is occurring. The EDDMs for the calculated MLCT transitions of complexes 1-3 are shown in Fig. 6. As expected, that the lower energy bands in the experimental spectrum arise from transitions that are mainly metal-to-ligand charge transfer (MLCT) in nature, while the higher-energy bands are due to transitions that involve ligand $\pi$ $\pi^{*}$ excitations. The majority of the excited states in this study consist of more than one transition.

The TDDFT calculations for $\mathbf{1}$ suggest an MLCT transition at $514 \mathrm{~nm}(f=0.051$, the shoulder at lower-energy visible region) made up of HOMO- $\rightarrow$ LUMO, HOMO-1 $\rightarrow$ LUMO +1 , and HOMO $\rightarrow$ LUMO, in which the HOMO-1 and HOMO are mainly metal-based and the LUMO is ligand-based; in essence, this is describing an MLCT transition that is mostly delocalized on one of the coordinated TAP ligands which is in agreement to the experimental data. There is another peak at the edge of UV and visible regions at $407 \mathrm{~nm}(f=0.435)$ made up of HOMO-6 $\rightarrow$ LUMO+1, HOMO $-3 \rightarrow$ LUMO, HOMO-2 $\rightarrow$ LUMO which show mixed character of intra-ligand (IL) and MLCT transitions and the last peak in high energy region ( $321 \mathrm{~nm}, f=0.03$ ) with underestimated oscillator strength comparing to the large experimental molar extinction coefficient of this transition in the UV-Vis spectrum of the complex shows typical $\pi \rightarrow \pi^{*}$ transition in nature. Complex 2 shows the same behavior as $\mathbf{1}$ with a shoulder at lower-energy visible region (521 nm, $f=0.056$ ) which is mainly MLCT transition, a second in the high-energy visible region ( $407 \mathrm{~nm}, f=0.028$ ) which has mixed character of IL and MLCT transitions and the third (276 nm, $f=0.1$ ) in the UV region and is assigned as a $\pi \rightarrow \pi^{*}$ transition. The mixed character of IL and MLCT transitions in complex $\mathbf{2}$ is more pronounced than $\mathbf{1}$ and $\mathbf{3}$ due to the substituted hetero-aromatic ring on the coordinated ligands. The interesting feature of the theoretical and experimental UV-Vis spectra of complex $\mathbf{2}$ is the red-shift of the spectra by introducing heteroaromatic groups on ancillary ligands which is in agreement to the previous study [64]. Since 3 was not soluble in common organic solvents we were not able to compare the theoretical calculation with the experimental results but it shows the same behavior of $\mathbf{1}$ and $\mathbf{2}$, at least in theory. The second absorption band in $\mathbf{2}$ and $\mathbf{3}$ shows a mixed MLCT and $\pi \rightarrow \pi^{*}$ characters which are in agreement to the previously reported theoretical calculations of the $\mathrm{Cu}(\mathrm{I})$-substituted heterocyclic diimine complexes [63-65].

\section{Conclusions}

In this paper, for the first time, we report the synthesis of three new $\mathrm{Cu}(\mathrm{I})$ complexes bearing unsymmetrical tetraazaphenanthrene ligands. The molecular structures of the complexes are characterized by single-crystal X-ray diffraction and the four- 
coordinate geometries around $\mathrm{Cu}(\mathrm{I})$ are quantified using the $\tau_{4}$ parameter confirming significant effect of the interesting intermolecular $\pi \cdots \pi$ stacking and $\mathrm{C}-\mathrm{H}^{\cdots} \pi$ interactions between the aromatic ring moieties on the geometry around $\mathrm{Cu}(\mathrm{I})$ center. The use of DFT and TDDFT calculations was fundamental in elucidating the properties of the complexes in their electronic structures and their excited states. DFT calculations show that the HOMO is located on the metal and LUMO has ligand-based orbitals character in which each molecular orbital has been broken down in terms of a percentage contribution from the metal center, and the tetraazaphenanthrene ligands and visualized by density of states (DOS) spectrum which gives a better overview of the nature of the frontier orbitals, especially when neighboring orbitals are closely spaced. Also, TDDFT calculations are capable of describing the spectral features of our investigated complexes and the lowestenergy absorption spectra are dominant MLCT transitions which were confirmed by the results from electron density difference maps (EDDMs).

\section{Acknowledgements}

R.K. thanks Sharif University of Technology Research Council, Max Planck Institute for Biophysical Chemistry and Deutsches Elektronen-Synchrotron (DESY) for the research facilities. R.K. thanks Dr. A. Griffin and Andy Dorn from Agilent Company for the X-ray data collection of the samples and Dr. Frank Hempel from University of Erlangen for access to Agilent SuperNova diffractometer. S.T. thanks DFG, SFB 755 and SFB 1073 for financial support.

\section{Appendix A. Supplementary material}

CCDC 955603-955605 contain the supplementary crystallographic data for this paper. These data can be obtained free of charge from The Cambridge Crystallographic Data Centre via www.ccdc.cam.ac.uk/data_request/cif. Supplementary data associated with this article can be found, in the online version, at http:// dx.doi.org/10.1016/j.ica.2014.08.052.

\section{References}

[1] B. Minaev, E. Jansson, H. Ågren, J. Chem. Phys. 125 (2006) 234.

[2] B. Minaev, E. Jansson, S. Schrader, H. Ågren, Chem. Phys. 333 (2007) 157.

[3] H. Yersin, Top. Curr. Chem. 241 (2004) 1.

[4] C.A. Bignozzi, R. Argazzi, C.J. Kleverlaan, Chem. Soc. Rev. 29 (2000) 87.

[5] D. Felder, J.F. Nierengarten, F. Barigelletti, B. Ventura, N. Armaroli, J. Am. Chem. Soc. 123 (2001) 6291.

[6] J.C. Vickery, M.M. Olmstead, E.Y. Fung, A.L. Balch, Angew. Chem., Int. Ed. Engl. 36 (1997) 1179.

[7] M.A. Mansour, W.B. Connick, R.J. Lachicotte, H.J. Gysling, R. Eisenberg, J. Am. Chem. Soc. 120 (1998) 1329.

[8] J.N. Demas, B.A. DeGraff, Coord. Chem. Rev. 211 (2001) 317.

[9] J.R. Kirchhoff, D.R. McMillin, W.R. Robinson, D.R. Powell, A.T. McKenzie, S. Chen, Inorg. Chem. 24 (1985) 3928.

[10] C.E.A. Palmer, D.R. McMillin, Inorg. Chem. 26 (1987) 3837.

[11] R.M. Berger, D.R. McMillin, R.F. Dallinger, Inorg. Chem. 26 (1987) 3802.

[12] G. Blasse, P.A. Breddels, D.R. McMillin, Chem. Phys. Lett. 109 (1984) 24.

[13] K.L. Cunningham, C.R. Hecker, D.R. McMillin, Inorg. Chim. Acta 242 (1996) 143.

[14] C.T. Cunningham, J.J. Moore, K.L.H. Cunningham, P.E. Fanwick, D.R. McMillin, Inorg. Chem. 39 (2000) 3638.

[15] C.T. Cunningham, K.L.H. Cunningham, J.F. Michalec, D.R. McMillin, Inorg. Chem. 38 (1999) 4388.

[16] S. Sakaki, T. Kuroki, T. Hamada, Dalton Trans. (2002) 840.

[17] T. Bessho, E.C. Constable, M. Graetzel, A. Hernandez Redondo, C.E. Housecroft, W. Kylberg, Md.K. Nazeeruddin, M. Neuburger, S. Schaffner, Chem. Commun. (2008) 3717.

[18] B. Bozic-Weber, E.C. Constable, C.E. Housecroft, M. Neuburger, J.R. Price, Dalton Trans. 39 (2010) 3585.

[19] (a) B. Bozic-Weber, E.C. Constable, C.E. Housecroft, Coord. Chem. Rev. 257 (2013) 3089;

(b) M. Sandroni, L. Favereau, A. Planchat, H. Akdas-Kilig, N. Szuwarski, Y. Pellegrin, E. Blart, H. Le Bozec, M. Boujtita, F. Odobel, J. Mater. Chem. A 2 (2014) 9944.
[20] J. Huang, O. Buyukcakir, M.W. Mara, A. Coskun, N.M. Dimitrijevic, G. Barin, O. Kokhan, A.B. Stickrath, R. Ruppert, D.M. Tiede, J.F. Stoddart, J.-P. Sauvage, L.X. Chen, Angew. Chem., Int. Ed. 51 (2012) 12711.

[21] E. Müller, G. Bernardinelli, J. Reedijk, Inorg. Chem. 35 (1996) 1952.

[22] W.M. Davis, A. Zask, K. Nakanishi, S.J. Lippard, Inorg. Chem. 24 (1985) 3737.

[23] D.R. McMillin, J.R. Kirchhoff, K.V. Goodwin, Coord. Chem. Rev. 64 (1985) 83.

[24] D.V. Scaltrito, D.W. Thompson, J.A. O'Callaghan, G.J. Meyer, Coord. Chem. Rev. 208 (2000) 243.

[25] R.M. Everly, D.R. McMillin, Photochem. Photobiol. 50 (1989) 711.

[26] K. Karlsson, C. Moucheron, A. Kirsch-De, New J. Chem. 18 (1994) 721.

[27] C. Moucheron, K. Karlsson, C. Verhoeven, R. Nasielski-Hinkens, Tetrahedron Lett. 34 (7) (1993) 1163.

[28] J. Nasielski, R. Nasielski-Hinkens, S. Heilporn, C. Rypens, J.P. Declercq, Bull. Soc. Chim. Belg. 97 (1988) 983.

[29] F.H. Allen, Acta Crystallogr., Sect. B 58 (2002) 380.

[30] SciFinder, Version 2013; Chemical Abstract Service. Columbus, OH, 2013.

[31] S.-H. Kuang, D.G. Cuttell, D.R. McMillin, P.E. Fanwick, R.A. Walton, Inorg. Chem. 41 (2002) 3313.

[32] R.C. Clark, J.S. Reid, Acta Crystallogr., Sect. A 64 (1995) 887.

[33] SuperNova CCD System: Empirical absorption correction, CrysAlis-Software package, Oxford Diffraction Ltd, 2011.

[34] O.V. Dolomanov, L.J. Bourhis, R.J. Gildea, J.A.K. Howard, H. Puschmann, J. Appl. Crystallogr. 42 (2009) 339 and Agilent (2012). AutoChem2.0, in conjunction with OLEX2. Agilent Technologies UK Ltd, Yarnton, Oxfordshire, England.

[35] G.M. Sheldrick, Acta Crystallogr., Sect. A 64 (2008) 112.

[36] A.L. Spek, Acta Crystallogr., Sect. D 65 (2009) 148.

[37] I.A. Guzei, M. Wendt, Dalton Trans. (2006) 3991.

[38] A.D. Becke, J. Chem. Phys. 98 (1993) 5648.

[39] C. Lee, W. Yang, R.G. Parr, Phys. Rev. B: Condens. Matter 37 (1988) 785.

[40] M.J. Frisch, G.W. Trucks, H.B. Schlegel, G.E. Scuseria, M.A. Robb, J.R. Cheeseman, J.A. Montgomery Jr., T. Vreven, K.N. Kudin, J.C. Burant, J.M. Millam, S.S. Iyengar, J. Tomasi, V. Barone, B. Mennucci, M. Cossi, G. Scalmani, N. Rega, G.A. Petersson, H. Nakatsuji, M. Hada, M. Ehara, K. Toyota, R. Fukuda, J. Hasegawa, M. Ishida, T. Nakajima, Y. Honda, O. Kitao, H. Nakai, M. Klene, X. Li, J.E. Knox, H.P. Hratchian, J.B. Cross, V. Bakken, C. Adamo, J. Jaramillo, R. Gomperts, R.E. Stratmann, O. Yazyev, A.J. Austin, R. Cammi, C. Pomelli, J.W. Ochterski, P.Y. Ayala, K. Morokuma, G.A. Voth, P. Salvador, J.J. Dannenberg, V.G. Zakrzewski, S. Dapprich, A.D. Daniels, M.C. Strain, O. Farkas, D.K. Malick, A.D. Rabuck, K. Raghavachari, J.B. Foresman, J.V. Ortiz, Q. Cui, A.G. Baboul, S. Clifford, J. Cioslowski, B.B. Stefanov, G. Liu, A. Liashenko, P. Piskorz, I. Komaromi, R.L. Martin, D.J. Fox, T. Keith, M.A. Al-Laham, C.Y. Peng, A. Nanayakkara, M. Challacombe, P.M.W. Gill, B. Johnson, W. Chen, M.W. Wong, C. Gonzalez, J.A. Pople, Gaussian 03, Revision B.04, Gaussian Inc., Wallingford, CT, 2004.

[41] D. Andrae, U. Häußermann, M. Dolg, H. Stoll, H. Preuß, Theor. Chim. Acta 77 (1990) 123.

[42] R.E. Stratmann, G.E. Scuseria, M.J. Frisch, J. Chem. Phys. 109 (1998) 8218.

[43] V. Barone, M. Cossi, J. Phys. Chem. A102 (1998). 1995-200.

[44] M. Cossi, V. Barone, J. Chem. Phys. 115 (2001) 4708.

[45] M. Cossi, N. Rega, G. Scalmani, V. Barone, J. Comput. Chem. 24 (2003) 669.

[46] M.E. Casida, C. Jamorski, K.C. Casida, D.R. Salahub, J. Chem. Phys. 108 (1998) 4439.

[47] W.R. Browne, N.M. O’Boyle, J.J. McGarvey, J.G. Vos, Chem. Soc. Rev. 34 (2005) 641.

[48] N.M. O’Boyle, J.G. Vos, J. Comput. Chem. 29 (2008) 839.

[49] C.O. Dietrich-Buchecker, P.A. Marnot, J.-P. Sauvage, J.-P. Kintzinger, P. Maltese, Nouv. J. Chim. 8 (1984) 573.

[50] P.W. Hansen, P.W. Jensen, Spectrochim. Acta 50A (1994) 169.

[51] R.M. Everly, D.R. McMillin, J. Phys. Chem. 95 (1991) 9071.

[52] W.L. Parker, G.A. Crosby, J. Phys. Chem. 93 (1989) 5692.

[53] J.V. Lockard, S. Kabehie, J.I. Zink, G. Smolentsev, A. Soldatov, L.X. Chen, J. Phys. Chem. B 114 (2010) 14521.

[54] A.K. Ichinaga, J.R. Kirchhoff, D.R. Mcmillin, C.O. Dietrich-Buchecker, P.A. Marnot, J.P. Sauvage, Inorg. Chem. 26 (1987) 4290.

[55] Z.A. Siddique, Y. Yamamoto, T. Ohno, K. Nozaki, Inorg. Chem. 42 (2003) 6366.

[56] F.K. Klemens, C.E.A. Palmer, S.M. Rolland, P.E. Fanwick, D.R. McMillin, J.P. Sauvage, New J. Chem. 14 (1990) 129.

[57] Y. Pellegrin, M. Sandroni, E. Blart, A. Planchat, M. Evain, N.C. Bera, M. Kayanuma, M. Sliwa, M. Rebarz, O. Poizat, C. Daniel, F. Odobel, Inorg. Chem. 50 (2011) 11309.

[58] M.G. Fraser, H. van der Salm, S.A. Cameron, J.E. Barnsley, K.C. Gordon, Polyhedron 52 (2012) 623.

[59] L. Yang, D.R. Powell, R.P. Houser, Dalton Trans. (2007) 955.

[60] C. Janiak, Dalton Trans. (2000) 3885.

[61] S.R. Stoyanov, J.M. Villegas, D.P. Rillema, Inorg. Chem. 41 (2002) 2941.

[62] B. Bozic-Weber, V. Chaurin, E.C. Constable, C.E. Housecroft, M. Meuwly, M. Neuburger, J.A. Rudd, E. Schönhofer, L. Siegfrieda, Dalton Trans 41 (2012) 14157.

[63] X. Lu, C.-M.L. Wu, S. Wei, W. Guo, J. Phys. Chem. A114 (2010) 1178.

[64] X. Lu, S. Wei, C.-M.L. Wu, S. Li, W. Guo, J. Phys. Chem. C115 (2011) 3753.

[65] G. Burdzinski, T.L. Gustafson, J.C. Hackett, C.M. Hadad, M.S. Platz, J. Am. Chem. Soc. 127 (2005) 13764.

[66] K.B. Wiberg, C.M. Hadad, C.M. Breneman, K.E. Laidig, M.A. Murcko, T.J. LePage, Science 252 (1991) 1266 